Article

\title{
Evaluating the Changes from Endogranitic Magmatic to Magmatic-Hydrothermal Mineralization: The Zaaiplaats Tin Granites, Bushveld Igneous Complex, South Africa
}

\author{
Leonidas Vonopartis ${ }^{1, *(D)}$, Paul Nex ${ }^{1}\left(\mathbb{D}\right.$, Judith Kinnaird ${ }^{1}$ and Laurence Robb ${ }^{1,2,3}$ \\ 1 School of Geosciences, University of the Witwatersrand, Private Bag 3, Johannesburg 2050, South Africa; \\ Paul.Nex@wits.ac.za (P.N.); Judith.Kinnaird@wits.ac.za (J.K.); laurence.robb@earth.ox.ac.uk (L.R.) \\ Department of Earth Sciences, University of Oxford, Oxford OX1 3AN, UK \\ 3 Department of Geology, University of Johannesburg, P.O. Box, 524, Johannesburg 2006, South Africa \\ * Correspondence: Lvonopartis@gmail.com
}

Received: 24 March 2020; Accepted: 14 April 2020; Published: 23 April 2020

\begin{abstract}
The stanniferous granites of the Zaaiplaats Tin Field are part of the A-Type Lebowa Granite Suite, within the greater Bushveld Igneous Complex of northeast South Africa. The tin field comprises three granites: (1) the Nebo, a leucocratic, equigranular biotite granite; (2) The brick-red hypidiomorphic Bobbejaankop granite, which is extensively microclinized with chloritized biotite and characteristic synneusis-textured quartz; and (3) The variably altered roof facies of the Bobbejaankop granite known as the Lease microgranite. The Bobbejaankop and Lease granites were both extensively mined for cassiterite until 1989. The cassiterite is hosted in disseminations, miarolitic cavities, and within large hydrothermal, tourmalinized, and greisenized pipes and lenticular ore-bodies. An extensive petrological and whole-rock XRF and ICP-MS geochemical study, has provided new insight into the magmatic and magmatic-hydrothermal mineralization processes in these granites. Trace elements and Rayleigh Fractionation modelling suggest the sequential fractionation of the Nebo granite magma to be the origin of the Bobbejaankop granite. Incompatible elemental ratios, such as $\mathrm{Zr} / \mathrm{Hf}$ and $\mathrm{Nb} / \mathrm{Ta}$, record the influence of internally derived, F-rich, hydrothermal fluid accumulation within the roof of the Bobbejaankop granite. Thus, the Lease granite resulted from alteration of the partially crystallized Bobbejaankop granite, subsequent to fluid saturation, and the accumulation of a magmatic-hydrothermal, volatile-rich fluid in the granite cupola. The ratio of $\mathrm{Nb} / \mathrm{Ta}$, proved effective in distinguishing the magmatic and magmatic-hydrothermal transition within the Bobbejaankop granite. Elemental ratios reveal the differences between pre- and post-fluid saturation in the mineralizing regimes within the same pluton. Thus highlighting the effect that the location and degree of hydrothermal alteration have had on the distribution of endogranitic tin mineralization.
\end{abstract}

Keywords: XRF and ICP-MS; Zaaiplaats tin field; A-type granites; tin granites; fractionation; hydrothermal; cassiterite mineralization

\section{Introduction}

The Paleoproterozoic Bushveld Complex, in the northeast of South Africa, is the largest known layered igneous complex on Earth. It exceeds an area of $90,000 \mathrm{~km}^{2}$ and has a magma volume estimated at 450,000 $\mathrm{km}^{3}$, hosting some of the world's largest mineral deposits [1-3]. Despite decades of research, its origin is still debated [3,4]. Although recent work by Zeh et al. [5] on the origin of the Rustenburg Layered Suite has made a significant contribution, the origin of the granites remains poorly understood. 
The Lebowa Granite Suite of the Bushveld is the largest A-Type batholith on Earth. It is subdivided into various facies that includes the coarse-grained Nebo, Bobbejaankop, and Makhutso granites, and the fine-grained Klipkloof and Lease granites [4,6-9].

The Makapansberg escarpment, part of the Northern Limb of the Bushveld Igneous Complex, is known for tin mineralization, particularly within the Zaaiplaats tin fields (Figure 1) [6,7,9]. The Lebowa Granite Suite is host to polymetallic magmato-hydrothermal, endo- and exogranitic deposits, including the notable, world-class, Vergenoeg fluorite mine [6,7]. Cassiterite mineralization was discovered in 1908 in the roof of the Bobbejaankop and in the Lease granites and, soon after, two mines were established by the Zaaiplaats Tin Mining Company, on the farms of Groenfontein and later Zaaiplaats (Figure 2) [7,10]. Approximately 37,079 tons of tin were produced before the closure of the Zaaiplaats tin field in 1989 [7,10]. Cassiterite mineralization is hosted as low-grade disseminations, pods and unique, large, and remarkably mineralized hydrothermal pipe- and lens-shaped ore-bodies [8,11-16].

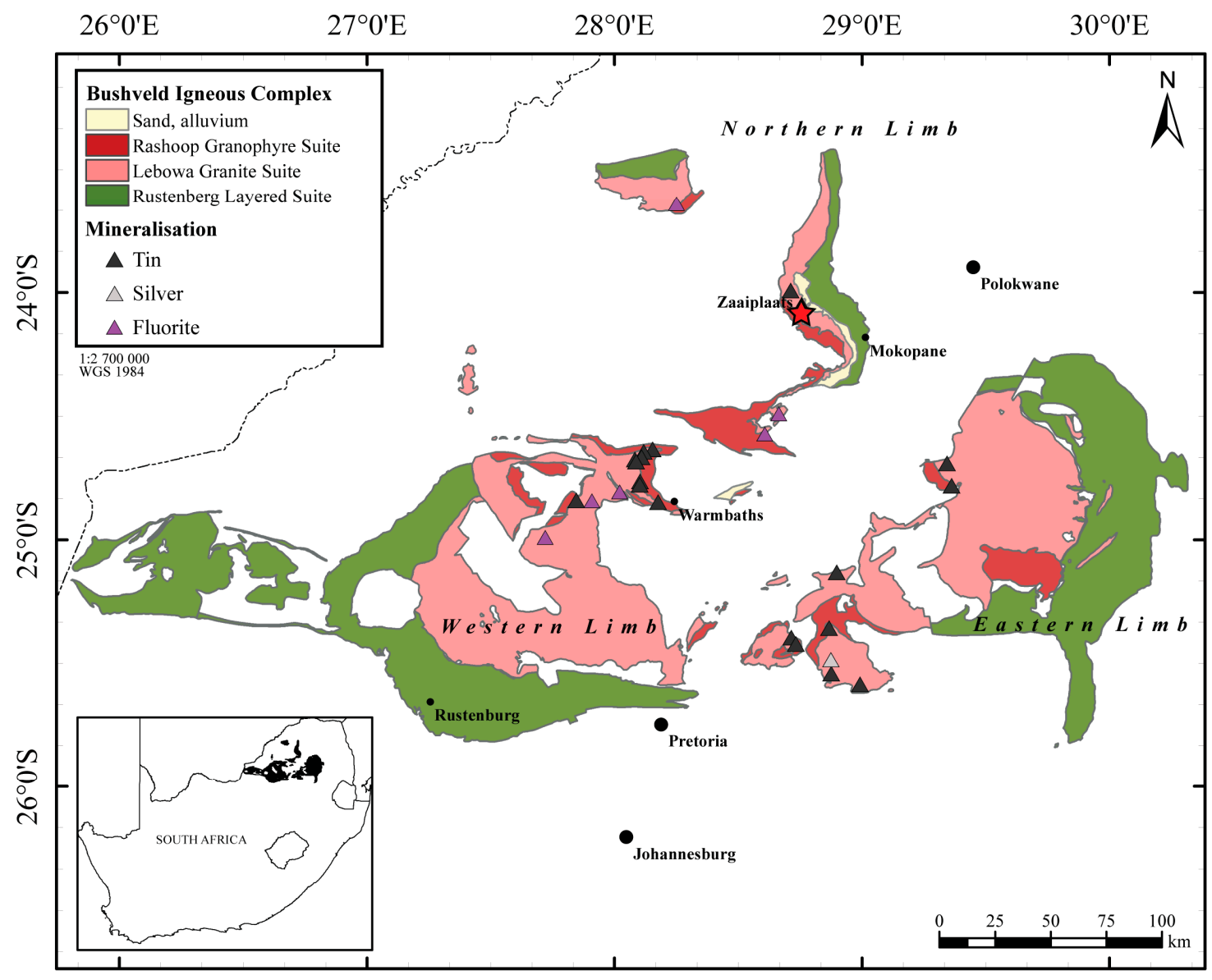

Figure 1. Simplified geological map of the Bushveld Igneous Complex showing the location of the Zaaiplaats tin field (red star) with other occurrences of tin, silver, and fluorite mineralization. Adapted from Hunter [17].

Various petrogenetic models for the formation of the granites and hydrothermal features of the Zaaiplaats tin field have been suggested. The Nebo granite was suggested to be the result of fractional crystallization from a bulk Nebo parent [12,18-20]. However, this model has subsequently been contested. For example, Hill et al. [21], suggested the formation of the granites from the partial melting of the Archean basement during the emplacement of the mafic to ultramafic Rustenburg Layered Suite. This resulted in multiple episodic ascending batches of siliceous melt. Wilson et al. [22] also proposed several different magmatic pulses that are petrographically, geochemically, and geophysically similar, yet distinct. The Bobbejaankop granite was suggested to be a metasomatised roof of the Nebo 
granite [4,20-24], whereas other models maintain that the Bobbejaankop granite was produced by fractional crystallization of the underlying Nebo granite [14,21,23-25].

The Lease granite was originally interpreted as a chilled margin to the Bobbejaankop granite, implying that it crystallized before the latter, although this concept has now been discarded $[7,13,14,26,27]$. Strauss and Truter [13] then proposed that the Lease granite formed as a post-reaction product from the accumulation of volatiles along the roof of the Bobbejaankop granite $[7,13,14,26,27]$. Alternative models suggest that the Lease granite resulted from quenching, induced by the fracturing of the volcanic roof rocks, or that the Bobbejaankop and Lease granites were produced by the local metasomatism of various types of Klipkloof granites [14,20,23,28]. However, most of the research conducted on understanding these granites has been focused on the Zaaiplaats tin mine, which is on the northern edge of the intrusion. Thus, since Strauss [27] and the closure of the Groenfontein tin mine in the early 1930s, the main body of the Bobbejaankop and Lease granites has been more or less neglected. Therefore, this study is focused at Groenfontein, with the aim of defining the petrogenetic relationship between the Lease and the Bobbejaankop granites, and to explain their origin and mineralization.

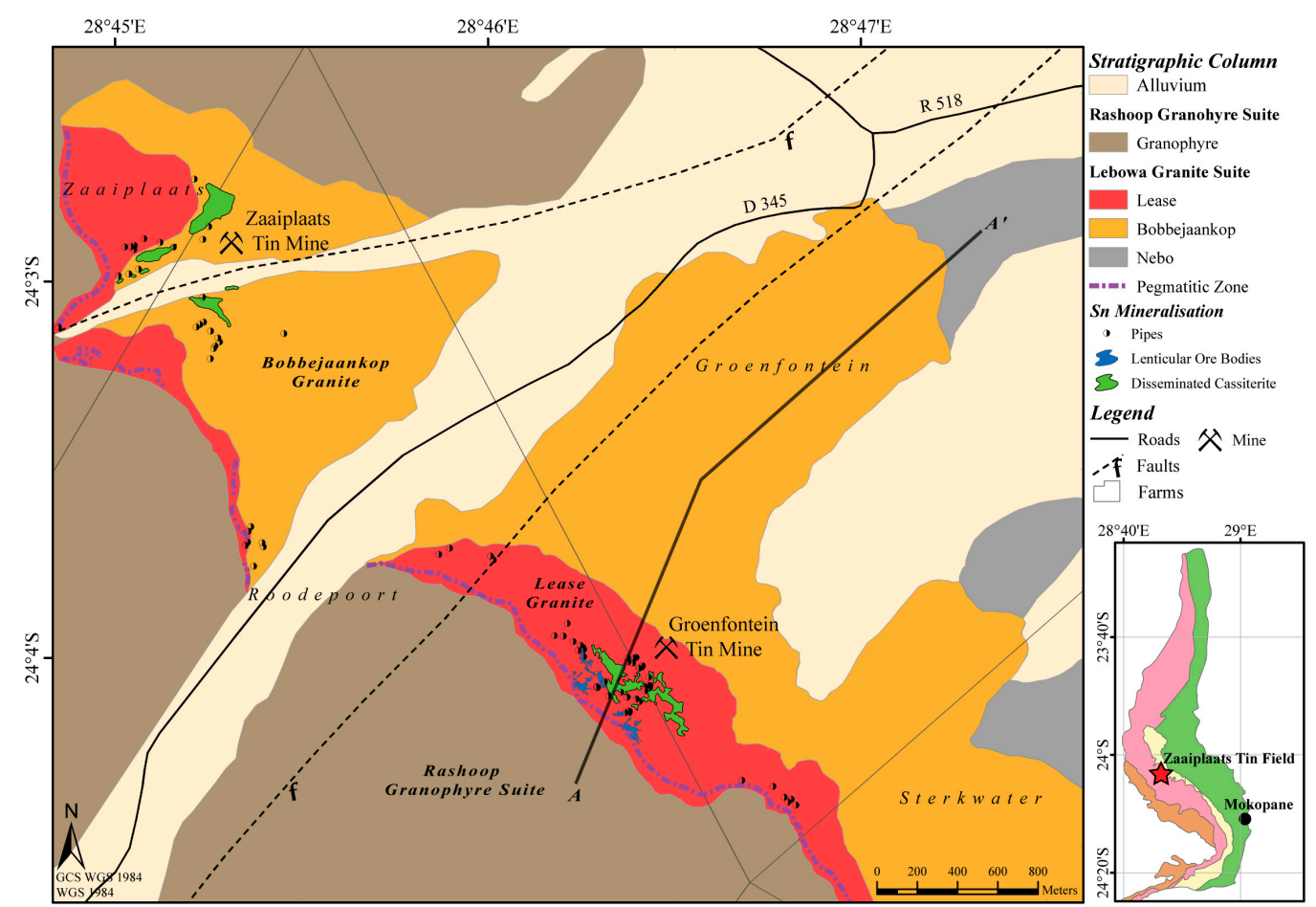

Figure 2. Revised geological map of the Zaaiplaats tin field. Lithological boundaries, disseminated mineralization, hydrothermal pipes and lenticular ore-bodies were validated by the integration of published geological maps and extensive field mapping [11,27]. Lithological nomenclature is based on SACS [29]. Cross section, shown in Figure 3, is along the line A- $\mathrm{A}^{\prime}$. The bottom right insert shows the location of the Zaaiplaats tin field (red star) on the Northern Limb of the Bushveld Igneous Complex. The lithological units are the same as in Figure 1.

\section{Regional Geology}

The Groenfontein tin mine is situated $30 \mathrm{~km}$ northwest of Mokopane and $2 \mathrm{~km}$ southeast of the Zaaiplaats tin mine (Figure 2). A sequence of sheeted granites comprise the majority of the region; the Nebo granite which is overlain by the Bobbejaankop and Lease granites, respectively. These granites are capped by the Rashoop Granophyre Suite and the entire sequence dips conformably between $10^{\circ}$ and $15^{\circ}$ westward (Figures 2 and 3) $[7,13,24]$. The Nebo granite is a 1.5 to $2.5 \mathrm{~km}$ thick sheeted granitic intrusion, composed of equigranular quartz, perthitic alkali-feldspar, hornblende, 
and biotite $[4,7,14,20,21]$. The Nebo progressively evolves from a grey, coarse-grained, mesocratic hornblende-bearing granite at its base, to a finer-grained, pinkish-red biotite granite in its roof facies within the Zaaiplaats region $[4,20,21]$. The Bobbejaankop granite is characterized as a brick-red, coarse-grained facies that is primarily composed of alkali-feldspar and synneusis-textured quartz, forming linked aggregates. It has variably chloritized biotite and miarolitic cavities, which are occasionally filled with cassiterite and minor tourmaline $[4,11,14,20,23,24]$.
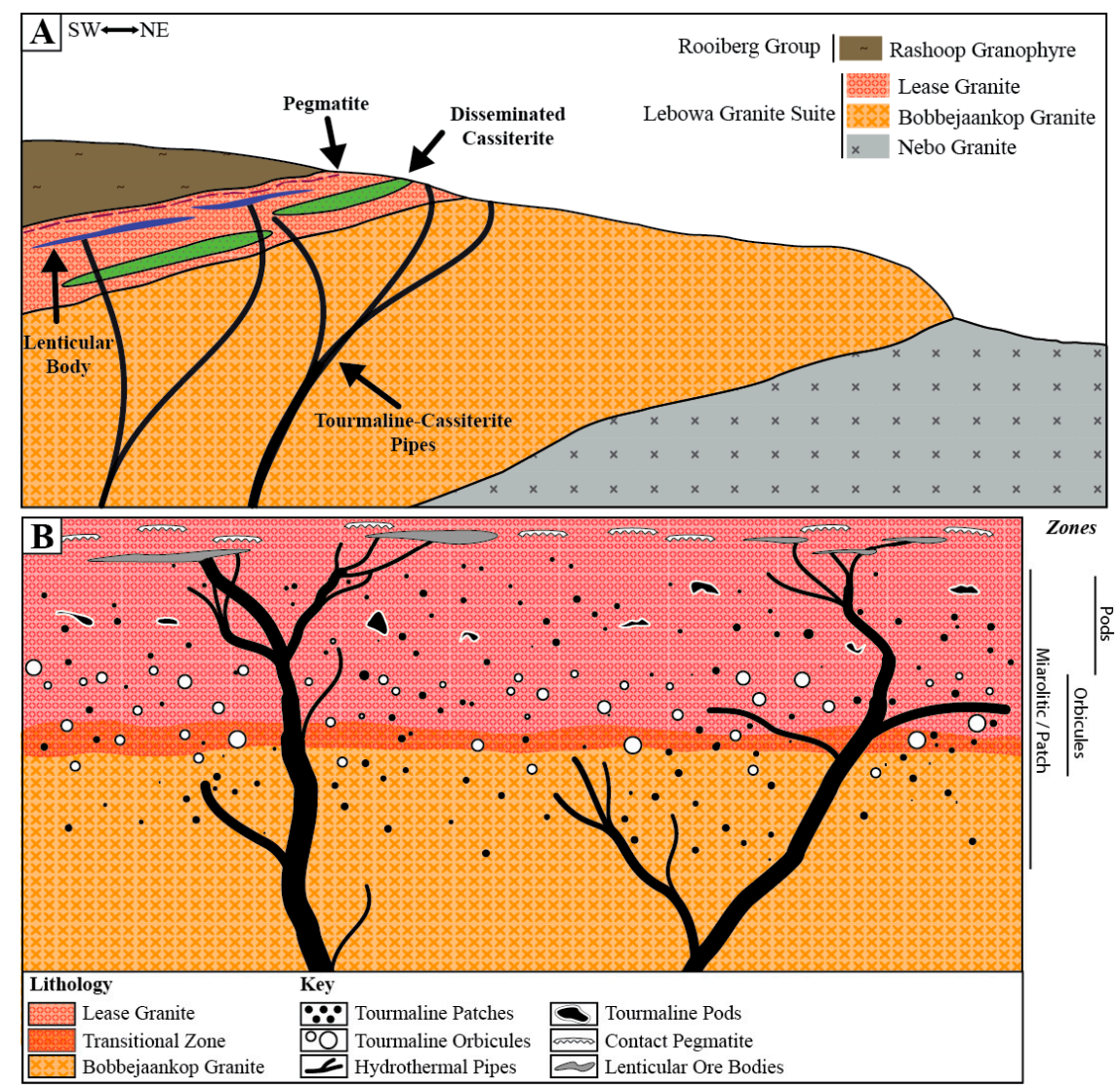

Figure 3. Schematic geological cross sections across the Groenfontein tin mine. (A) Schematic cross section from the Rashoop Granophyre Suite towards the Nebo granite (SW to NE) along line A-A' shown in Figure 1. (B) Schematic representation of a vertical cross section through the Lease and Bobbejaankop granites (NW to SE). A transitional zone rather than a sharp contact between the Bobbejaankop and Lease granites is suggested. The zones where the various types of tourmaline features occur are represented by the bars on the right side of the diagram.

The Lease granite is a relatively thin (120 m thick), lenticular sheet that is restricted to the roof of the Bobbejaankop granite, beneath the Rashoop Granophyre Suite (Figure 3). The Lease granite is described as a metasomatically altered red microgranite, exhibiting pervasive sericitic alteration in feldspars, extensive chloritization of biotite, patches of epidotization, and zones of disseminated cassiterite $[4,7,13,14,26]$. The mineralization at Groenfontein is confined to the upper $20 \mathrm{~m}$ of the Lease granite, 3 to $10 \mathrm{~m}$ below the contact pegmatite (Figure 3) [7,11-13,27]. These discontinuous lensoidal pegmatites are 2 to $5 \mathrm{~m}$ in length and have been used to demarcate the otherwise cryptic contact between the Lease granite and the Rashoop Granophyre Suite. The pegmatite lenses are usually unmineralized and primarily composed of pegmatitic quartz and reddened feldspars. Cassiterite is typically disseminated, although it does occur as small clusters and within lenticular and pipe-like ore bodies (Figure 3) [7,12,13,26]. The mineralization at Zaaiplaats occurs dominantly as cassiterite with accessory scheelite, sulfides, fluorite, and molybdenite, compared to Groenfontein, which is mainly cassiterite, with minor scheelite, and molybdenite $[7,12-14,26]$. 


\section{Petrography and Field Relationships}

The network of hydrothermal pipes and lenticular ore-bodies have been comprehensively discussed in a number of publications $[7,13-16,24,27,30]$. Therefore, these features are only briefly described here.

The contact between the Nebo and Bobbejaankop granites is marked by an upward gradational reddening of the feldspars and increasingly aggregated quartz. This gradation is almost imperceptible, as the contact zone occurs over several meters and is marked by a subtle break in slope. The nature of the obscure contact is corroborated by observations made by Strauss and Truter [13], Strauss [27] and Coetzee [11]. The Bobbejaankop granite forms an elongated sheeted intrusion, extending from the middle of the farm Zaaiplaats $223 \mathrm{KR}$ in the northwest, towards the southeast along the strike of the Northern limb (Figure 2). It extends from Roodepoort $222 \mathrm{KR}$ through Groenfontein $227 \mathrm{KR}$, before terminating along the boundary of Sterkwater 296 KR and Solomons Temple 230 KR.

The Bobbejaankop granite is typically composed of subhedral quartz $(0.5$ to $3 \mathrm{~mm}, 35 \%)$ with sub- to anhedral alkali-feldspar ( 0.5 to $6 \mathrm{~mm}, 35 \%$ ) and plagioclase $(<0.1$ to $0.5 \mathrm{~mm}, 25 \%)$, as well as extensively chloritized, interstitial magmatic biotite $(<0.1$ to $1 \mathrm{~mm},<5 \%)$. The quartz grains are transparent, granular, hypidiomorphic and typically display synneusis-textures, for which the Bobbejaankop is well known. Small $(<0.1 \mathrm{~mm})$ feldspar and chlorite inclusions are a common feature within the quartz grains. The perthitic feldspars of the Bobbejaankop granite are remarkably turbid in the thin section. The perthite ( 0.5 to $3 \mathrm{~mm}$ ) exhibits randomly distributed irregular patches ( $<0.1$ to $1 \mathrm{~mm}$ ) of exsolved plagioclase, delineated by a diffuse contact zone between the two species (Figure 4A). The exsolution of plagioclase within the host alkali-feldspar exists as patch, chessboard, and veined variants (Figure 4B). The plagioclase exhibits polysynthetic twinning and is selectively sericitized (Figure 4). Microclinized feldspars become brick-red, which is considered a result of hematitic coating by the exclusion of Fe from the feldspar (Figure 4A). This is accomplished during the crystallographic reordering of the feldspar lattice during deuteric sub-solidus microclinization, allowing the precipitation of $\mathrm{Fe}$, which then lined microcavities within the feldspars as hematite [31,32]. Plagioclase is selectively sericitized within the perthites by a very fine-grained pale green/white micaceous aggregate. Sericitization has replaced feldspar, biotite, and chlorite, in the upper facies of the granite.

Essentially, all magmatic biotites $(<0.1$ to $1 \mathrm{~mm}$ ) are extensively chloritized and partially stained red from the exclusion of Fe along the mineral boundaries and cleavages. Relict brown magmatic biotites are visible within the dark-green/brown chlorite (Figure 5A). Small anhedral grains of quartz, feldspar, and purple fluorite are intergrown with, and form inclusions within, the chlorite (Figure 5B). Chloritization of the biotite and feldspars increases towards the Lease granite. Miarolitic cavities ( 0.5 to $5 \mathrm{~cm}$ ) are common and typically filled with small clusters of intergrown spherulitic tourmaline and quartz (Figure 6). These cavities are scattered throughout the upper facies of the Bobbejaankop granite, although concentrated proximal to larger pipes. Some miarolitic cavities display a unidirectional solidification texture of quartz, reddened feldspars, fluorite, and calcite (Figure 5B). Fluorite is ubiquitous in the Bobbejaankop granite as inclusions in quartz and feldspar, within miarolitic cavities and interstitially. It is typically purple, with lesser transparent, white, and green varieties. Tourmaline within the Bobbejaankop granite primarily occurs as orbicules and in hydrothermal pipes, although it is also present in miarolitic cavities. Tourmaline-bearing miarolitic cavities comprise a central zone of calcite, subhedral cassiterite and fluorite, surrounded by a radial blue/green to brown tourmaline (Figure 6).

Ilmenite and sulfides ( 0.5 to $1.5 \mathrm{~mm}$ ) such as pyrite and chalcopyrite with lesser arsenopyrite are uncommon, although, where they do occur, they are associated with chloritization. The paragenetic sequence of the sulfides is suggested as early arsenopyrite, followed by pyrite and later chalcopyrite. Cassiterite is uncommon in the Bobbejaankop granite at Groenfontein and is restricted to tourmalinebearing miarolitic cavities. Minor subhedral $100 \mu \mathrm{m}$-sized zircons are associated with biotite. Most miarolitic cavities appear to have experienced various stages of hydrothermal alteration, with a suggested sequence of microclinization, chloritization, sericitization then hematization. 

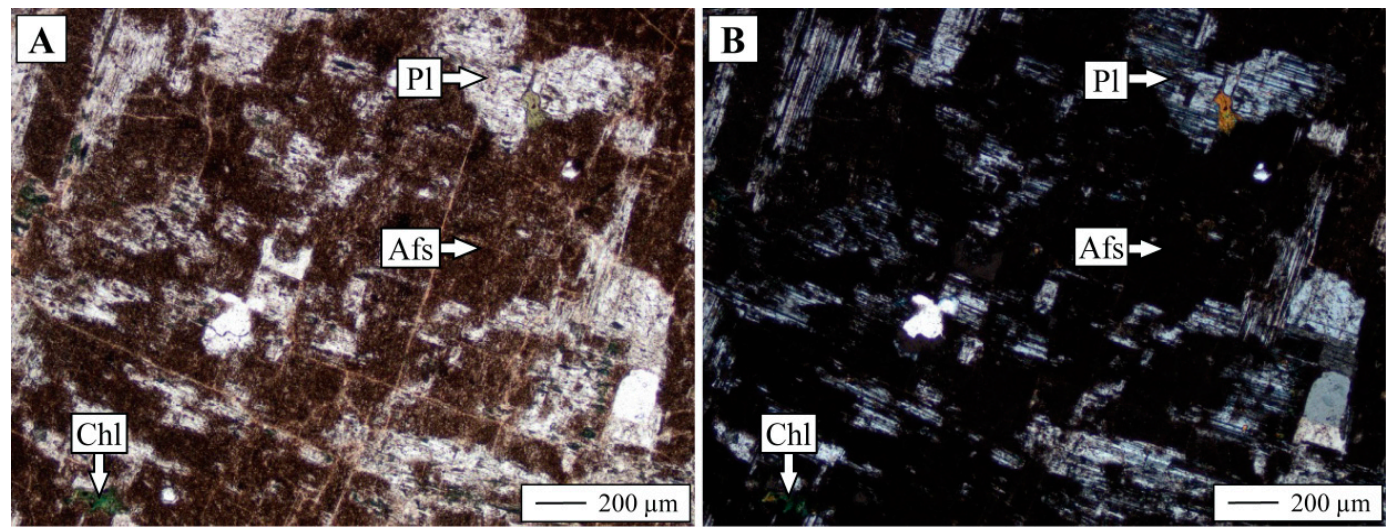

Figure 4. Photomicrographs of the Bobbejaankop granite. (A) PPL image of patch perthite. Within the perthite there are red alkali-feldspars (Afs), with patches of plagioclase ( $\mathrm{Pl}$ ) exsolution, which follows no apparent crystallographic orientation. Chlorite $(\mathrm{Chl})$ is seen selectively replacing plagioclase within the perthite grain. (B) XPL image of (A), depicting the polysynthetic twinning of the plagioclase exsolution within the perthite.
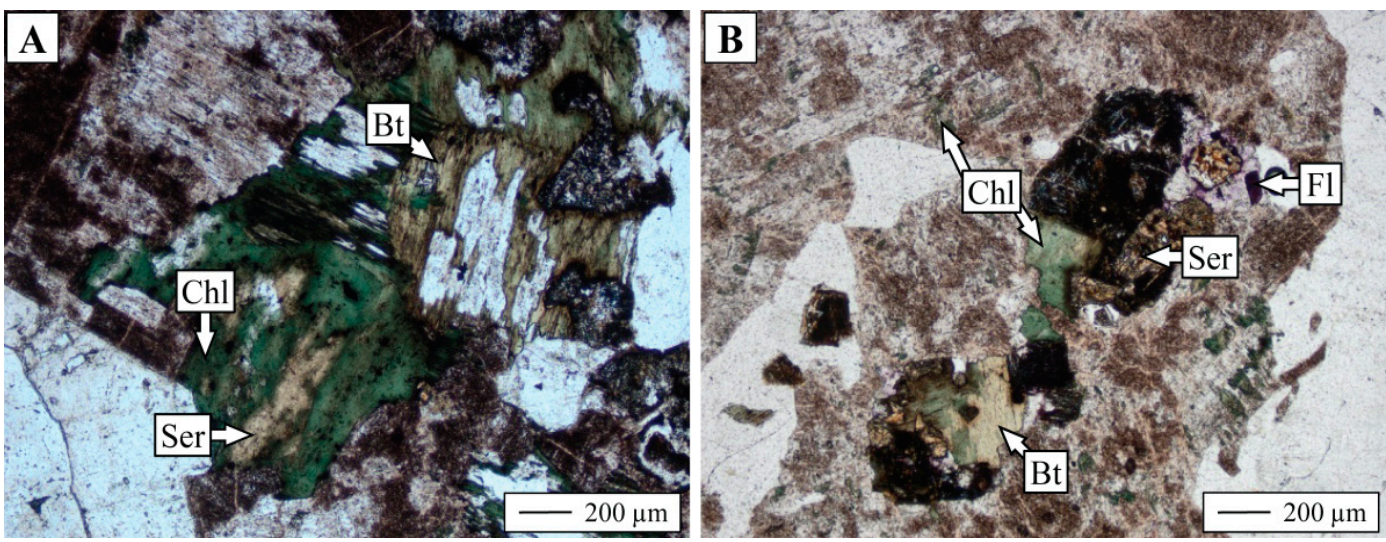

Figure 5. Photomicrographs of the Bobbejaankop granite. (A) PPL image of interstitial magmatic biotite (Bt) exhibiting chloritization (Chl) followed by sericitization (Ser). (B) PPL image of the intergrowth of biotite with fluorite $(\mathrm{Fl})$ within a miarolitic cavity that was subsequently chloritized and sericitized.
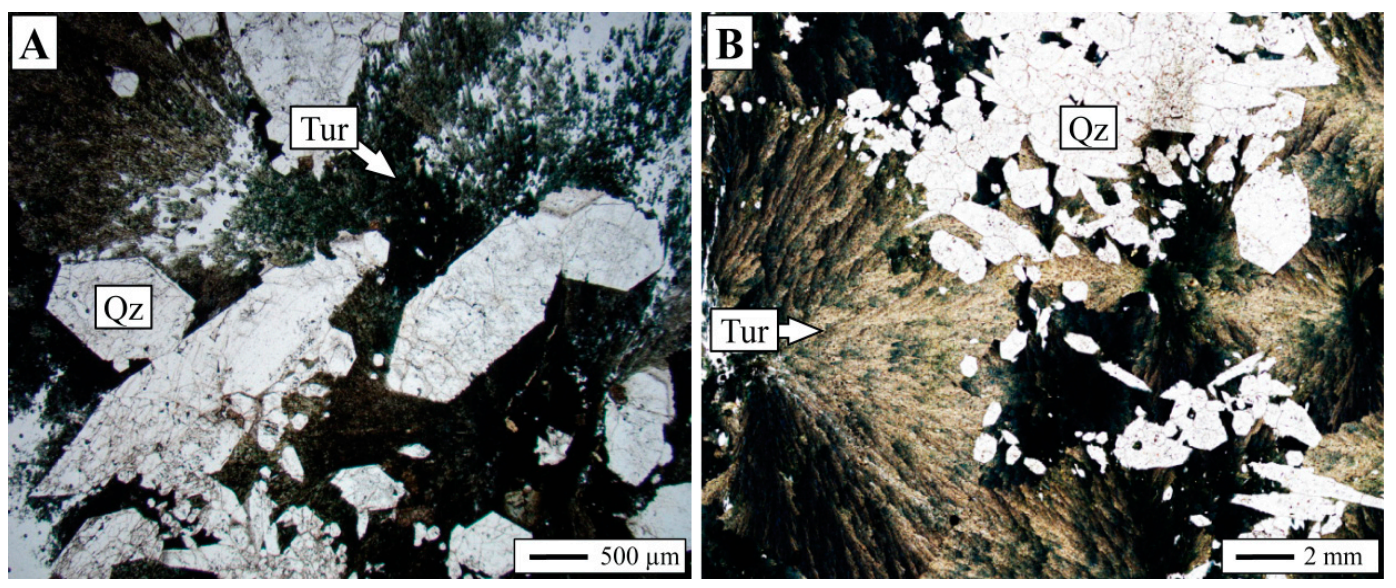

Figure 6. Photomicrographs from the Bobbejaankop granite. (A) PPL image of a tourmaline-quartz vug exhibiting acicular brown/green tourmaline (Tur) intergrown with euhedral quartz (Qz). Doubly terminated quartz crystals occur within these vugs. (B) PPL image of a tourmaline-quartz vug showing radial blue/brown tourmaline with euhedral quartz. 
Towards its upper contact, the Bobbejaankop granite exhibits features characteristic of the Lease granite, such as an increase in microclinization, chloritization, sericitization, granophyric intergrowths, and fluorite. A radial granophyric texture forms around the edges of the larger feldspar grains, becoming finer-grained and increasingly intergrown with perthite. The pervasive microclinization, associated with the hematization of feldspars, resulted in a purple/maroon coloration (Figure 7). Initially, microclinization selectively affected the feldspars, however, towards the Lease granite, the alteration gradually destroys the synneusis-textured quartz and increased granophyric intergrowths, resulting in an overall reduction in grain size (Figure 7). Although the contact between the Bobbejaankop and Lease granites has been described as sharp $[7,11,26,27]$, it appears to be gradational over 0.5 to $4 \mathrm{~m}$. As microclinization intensified, quartz synneusis was replaced by granophyric intergrowths and grain-size was reduced within the Bobbejaankop granite as it grades imperceptibly into the fine-grained Lease granite (Figure 7).

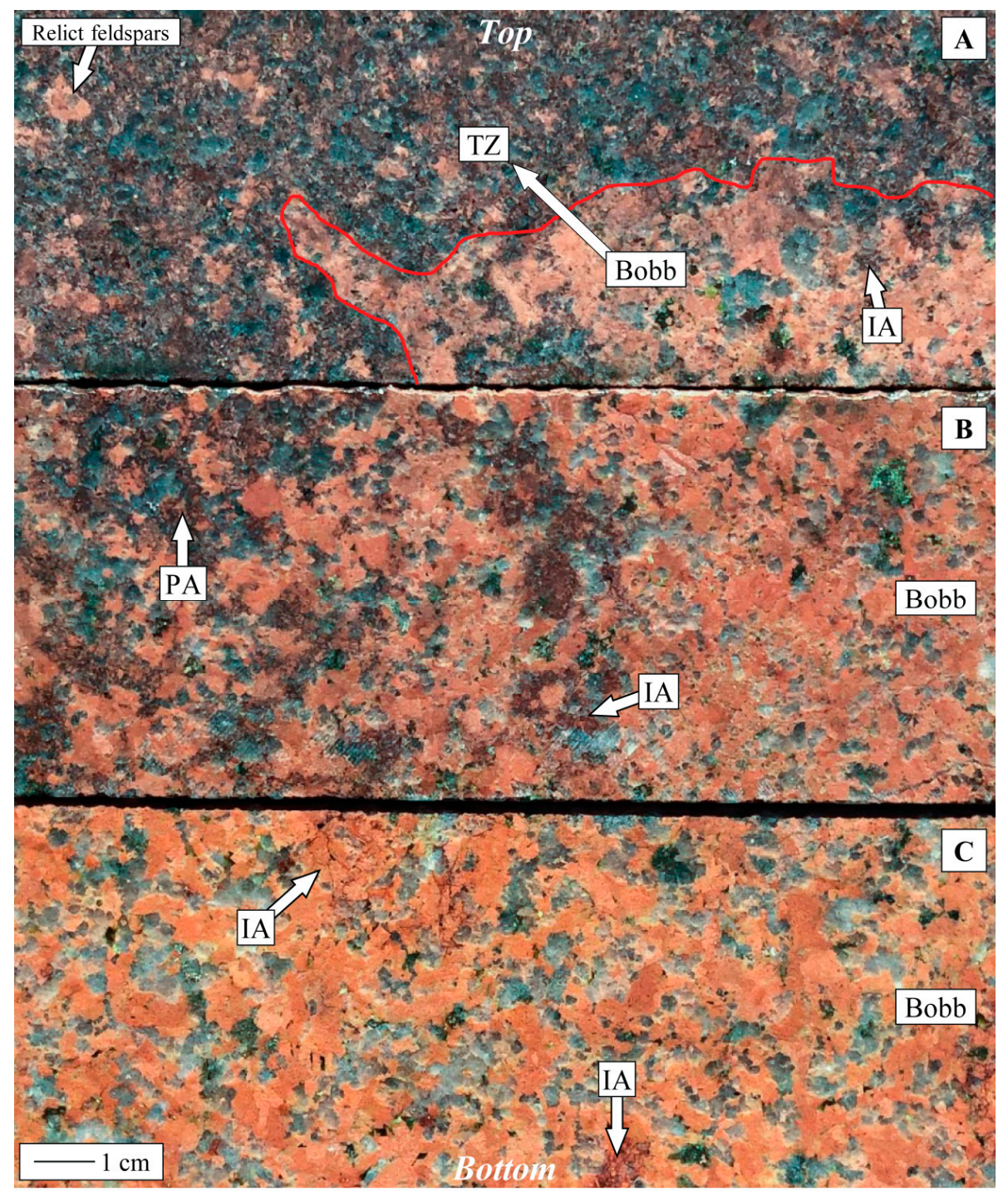

Figure 7. A collage of images of core from the top of the Bobbejaankop granite into the transitional zone. (A) Pink Bobbejaankop granite (Bobb) altering into the transitional zone (TZ). Selective microclinization of the feldspars is present as a maroon incipient alteration (IA) within the pink Bobbejaankop granite. However, from the transitional zone it is present as pervasive alteration (PA). (B) Brick-red Bobbejaankop granite exhibits patches of selective incipient microclinization that become pervasive towards the upper contact. (C) Typical Bobbejaankop granite towards the bottom of the core, showing minor incipient purple patches of microclinization. 
The Lease granite is heterogeneous, alternating between fine- and coarse-grained, and between a dull-red, pale-green, and a maroon-purple facies with no obvious systematic control (Figure 8). Overall it is typically finest-grained in its roof facies $(<0.5 \mathrm{~mm})$ and coarsest at the base (1 to $2 \mathrm{~mm})$. However, differences in grain size, color, and mineralogy provide a basis for the distinction of three facies of Lease (Table 1). The transitions between these types are either sharp or gradational and occasionally meet at a nexus (Figure 8). The mineralogy varies depending on the facies of Lease granite, however, it is characteristically composed of hypidiomorphic quartz and red feldspars with variable amounts of chlorite, biotite and fluorite. Quartz-lined miarolitic cavities $(2$ to $10 \mathrm{~cm}$ ) are composed of calcite, white-purple fluorite, and, occasionally, large euhedral cassiterite $(0.1$ to $2 \mathrm{~cm})$ with minor tourmaline.

Table 1. Mineralogical variations in the different facies of Lease granite.

\begin{tabular}{|c|c|c|c|c|c|c|}
\hline Type & Color & Grain Size & Mineralogy & Alteration & Mineralization & Description \\
\hline 1 & Red & $\begin{array}{l}<0.2 \text { to } \\
0.5 \mathrm{~cm}\end{array}$ & $\begin{array}{l}\text { Quartz and } \\
\text { reddened feldspars, } \\
\text { minor chlorite and } \\
\text { biotite }\end{array}$ & $\begin{array}{l}\text { Microclinization } \\
\text { and } \\
\text { chloritization }\end{array}$ & $\begin{array}{l}\text { Minor cassiterite } \\
\text { within miarolitic } \\
\text { cavities }\end{array}$ & $\begin{array}{l}\text { Typical appearance of the Lease } \\
\text { granite. Generally } \\
\text { coarser-grained at the base and } \\
\text { finer in the roof facies. }\end{array}$ \\
\hline 2 & Maroon & $\begin{array}{l}<0.1 \text { to } \\
0.5 \mathrm{~mm}\end{array}$ & $\begin{array}{l}\text { Increased fluorite, } \\
\text { epidote, miarolitic } \\
\text { cavities, and } \\
\text { chloritization of } \\
\text { biotite }\end{array}$ & $\begin{array}{c}\text { Increased } \\
\text { microclinization, } \\
\text { chloritization, } \\
\text { and } \\
\text { epidotization }\end{array}$ & $\begin{array}{l}\text { Disseminated } \\
\text { cassiterite } \\
\text { hosted in } \\
\text { miarolitic } \\
\text { cavities }\end{array}$ & $\begin{array}{l}\text { Finest-grained facies of the } \\
\text { Lease granite. Associated with } \\
\text { disseminated cassiterite }\end{array}$ \\
\hline 3 & Green & $<0.2 \mathrm{~cm}$ & $\begin{array}{l}\text { Increased quartz, } \\
\text { chlorite, sericite, } \\
\text { and tourmaline }\end{array}$ & $\begin{array}{l}\text { Greater degree } \\
\text { of greisenization }\end{array}$ & $\begin{array}{l}\text { Minor cassiterite } \\
\text { present in } \\
\text { cavities and } \\
\text { dissemination }\end{array}$ & $\begin{array}{l}\text { Similar mineralogy and grain } \\
\text { size to Type } 1 \text { although has } \\
\text { greater greisenization resulting } \\
\text { in the green tinge. This facies } \\
\text { usually exists as an alteration } \\
\text { halo around pipes }\end{array}$ \\
\hline
\end{tabular}

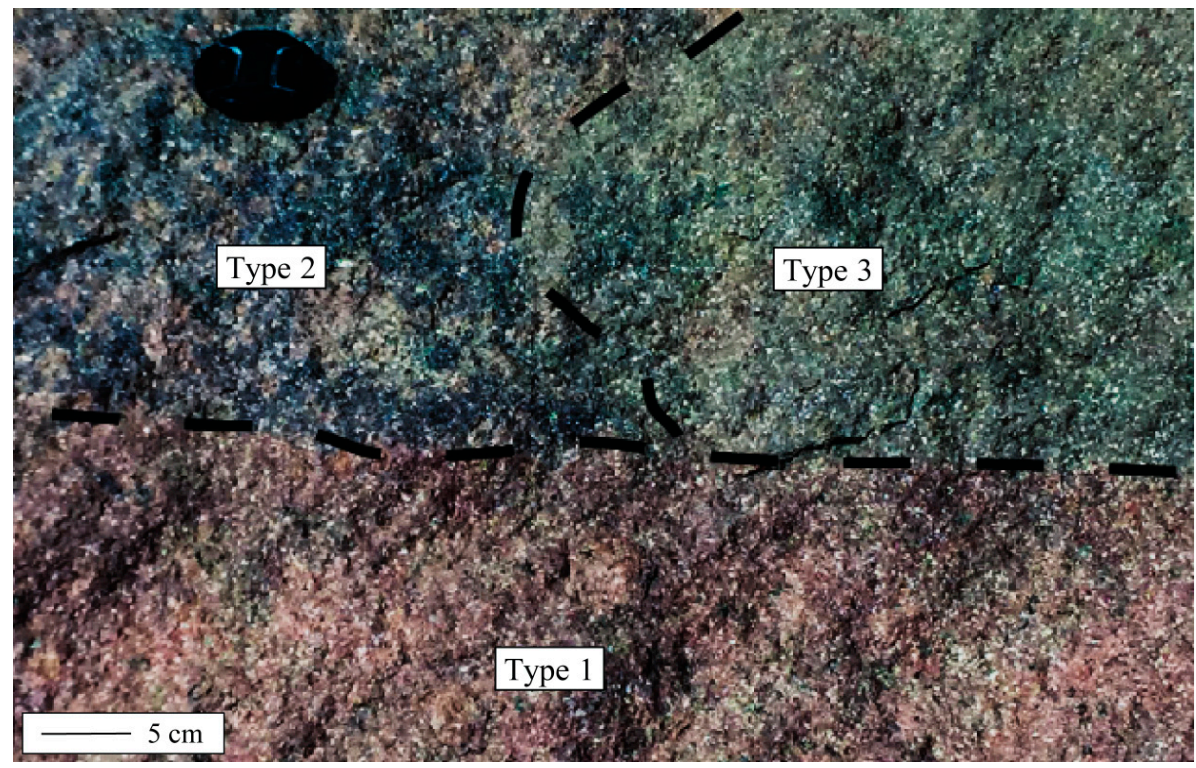

Figure 8. Surface features of the three Lease granite variants.

Type 1 is the most abundant, and can be considered the typical, "baseline" Lease granite. Typical Lease is brick-red, fine-grained, and composed of sub- to anhedral graphically intergrown quartz and perthite (Figure 9A). Quartz has lost its synneusis texture, becoming fine-grained, more rounded and anhedral (0.2 to $1.2 \mathrm{~mm}, 35 \%$ ) (Figure 9). The feldspars become more turbid and redder than in the Bobbejaankop granite, with the alkali-feldspar (0.5 to $1 \mathrm{~mm}, 35 \%)$ and plagioclase grains $(<0.2 \mathrm{~mm}, 20 \%)$ becoming smaller and increasingly altered. Biotite is larger $(0.5$ to $1 \mathrm{~cm}, 8 \%)$ than in the Bobbejaankop granite and typically interstitial, sub- to anhedral, and extensively chloritized with subsequent sericitization (Figure 9D). The exclusion of Fe and Ti from the biotite during chloritization 
results in reddening of the mineral edges and rutile crystallization within the chlorite (Figure 9D). Interstitial subhedral fluorites $(0.1$ to $0.4 \mathrm{~mm}, 1 \%)$ are more common, with lesser amounts of epidote and calcite ( 0.1 to $0.4 \mathrm{~mm},<1 \%$ ). Feldspars exhibit patch, snowball, and chessboard exsolution textures and are highly sericitized. The zones of granophyric intergrowth are purely quartz and feldspar with few interstitial or included phases. Miarolitic cavities are common in these facies of the Lease, with amygdales composed of calcite and inward-projecting euhedral quartz and feldspars. Small $(<10 \mu \mathrm{m})$ inclusions of chloritized biotite and fluorite are present within quartz and perthite (Figure 9C,D).
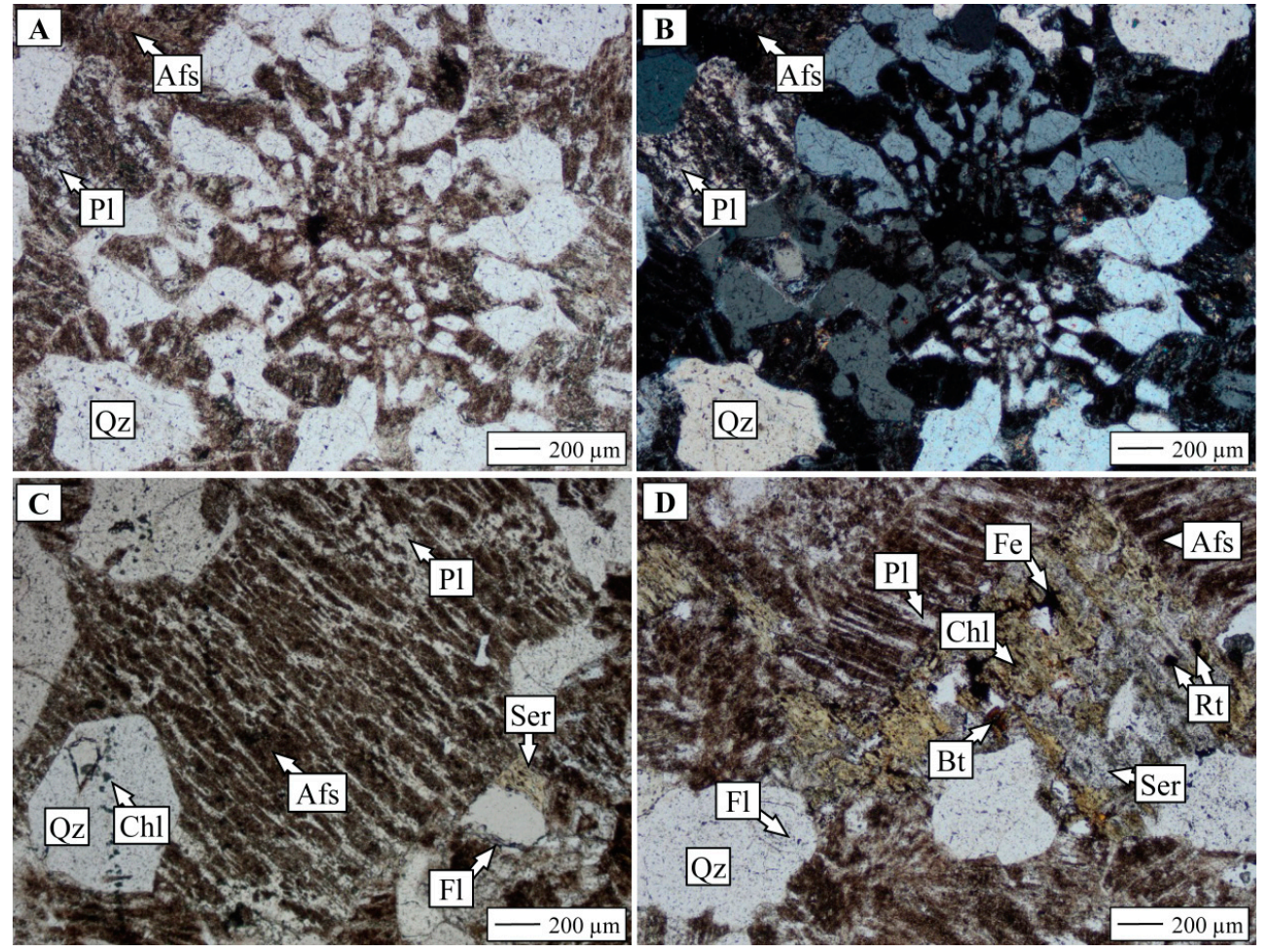

Figure 9. Photomicrographs from the Lease granite. (A) PPL image of granophyric texture of the Lease granite. (B) XPL image of alkali-feldspar (Afs), showing the granophyric overprinting of larger quartz $(\mathrm{Qz})$ grains, which are optically continuous. The plagioclase $(\mathrm{Pl})$ exsolution within the perthite exhibits selective replacement by sericite. (C) PPL image showing veined exsolution of perthite and multiple small chlorite (Chl) inclusions within quartz and a miarolitic cavity filled with sericite (Ser) and fluorite (Fl). (D) PPL image showing chloritized, and later sericitized, interstitial biotite (Bt). Iron-staining (Fe) coats the edges of the chloritized biotite and small growths of rutile (Rt) are present. Small fluorite inclusions are scattered within the quartz and perthites.

Miarolitic cavities are common within the Type 1 Lease, particularly proximal and parallel to the Bobbejaankop contact and roof. Cross-cutting calcite veins are associated with a minor sulfide assemblage of pyrite and lesser chalcopyrite. Miarolitic cavities are typically surrounded by a 1 to $1.5 \mathrm{~cm}$ wide zone of highly sericitized granophyric quartz and perthite. Approximately $5 \mathrm{~m}$ above and parallel to the Bobbejaankop-Lease contact, there is a $1 \mathrm{~m}$ thick zone of circular, tourmaline orbicules ( 1 to $20 \mathrm{~cm}$ ), comprising a melanocratic tourmaline-quartz core surrounded by a halo of leucocratic quartz-tourmaline with minor cassiterite, fluorite and calcite.

Type 2 Lease granite is a maroon/purple variety, mineralogically similar to Type 1, although exhibiting a distinct decreased grain size $(<0.1$ to $0.5 \mathrm{~mm})$, increase in microclinization, granophyric texture, and accessory fluorite. Granophyric quartz displays an optical continuity that delineates much larger grains (Figure 9B). Increased microclinization and hematization of the feldspars produced a maroon appearance, which was subsequently overprinted by chloritization then sericitization. Accessory ilmenite and sulfides, associated with biotite alteration, including pyrite and chalcopyrite 
(0.2 to $0.3 \mathrm{~mm}$ ), are more abundant than in the Bobbejaankop granite. Cassiterite is red-brown, medium-grained (0.5 to $0.7 \mathrm{~mm}$ ), sub- to euhedral and rarely shows zonation. It occurs within miarolitic cavities as inclusions, and it appears to have exsolved during chloritization, alongside sulfides, decorating relict biotite cleavage. These exsolutions amalgamate on the mineral edges, forming euhedral crystals (Figure 10).
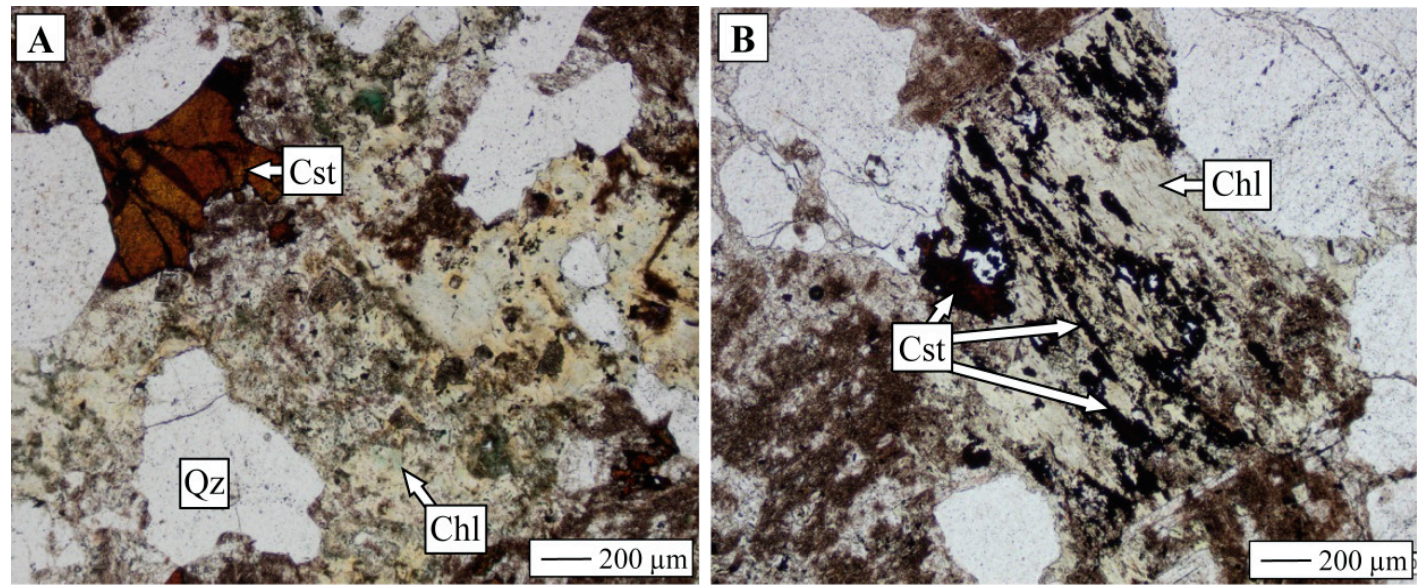

Figure 10. Photomicrographs from the Type 2 Lease. (A) PPL image of an anhedral cassiterite (Cst) grain associated with extensively chloritized (Chl) biotite surrounded by perthite and quartz (Qz). (B) PPL image showing the exclusion of Sn along the cleavages of the chloritized biotite, which accumulated into discrete grains of cassiterite along the periphery of the chlorite.

Type 3 is the pale green facies of the Lease granite that is restricted to zones of extensive sericitization, particularly surrounding pipe-like and lenticular bodies. This facies is similar to Type 1 , however there is a notable increase in pervasive over-printing of sericitization and, to a lesser extent, silicification. Perthites are extensively digested with only skeletal perthites remaining (Figure 11A,B). Plagioclase is replaced by very fine-grained white mica, quartz, and fluorite, leaving the anhedral, reddened alkali-feldspars in a fine-grained greisenized groundmass. Microcrystalline or fine-grained anhedral quartz appears to have replaced the original quartz grains within and surrounding the relic feldspar grains, retaining their graphic texture. Tourmaline within this facies is more prominent, and displayed as incipient tourmalinization of feldspars that has produced nests and interlocking fans of acicular radiating blue-green tourmalines (Figure 11C,D). These tourmaline nests are intergrown with white mica and quartz within miarolitic cavities and occasionally host euhedral cassiterite (Figure 11D).

The roof of the Lease granite is poorly exposed and demarcated by a zone of discontinuous, laterally extensive pegmatites which are interfingered with Type 1 Lease (Figure 2). These irregularly shaped, lensoidal pegmatites are $5 \mathrm{~m}$ below the Rashoop Granophyre Suite contact and range from $1 \times 5 \mathrm{~cm}$ to $0.05 \times 0.7 \mathrm{~m}$ in size. They are composed of pegmatitic quartz and red feldspar, exhibiting perpendicular growth inwards from the roof and base, indicative of a unidirectional silicification texture (UST). Subhedral biotite, variably colored fluorite, and calcite are commonly interstitial phases. Söhnge [30] recorded mineable occurrences of cassiterite and scheelite, but these were not observed in the present study. 

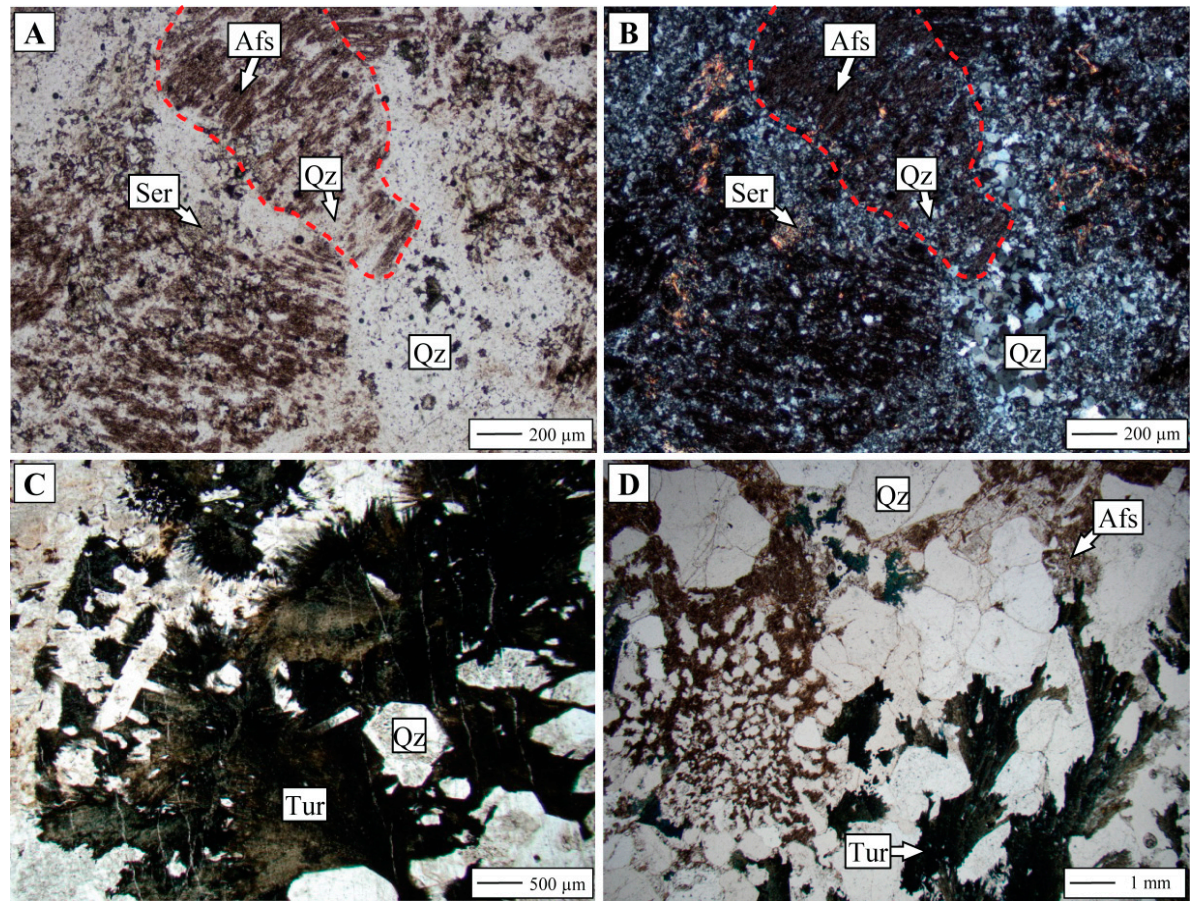

Figure 11. Photomicrographs from Type 3 Lease granite. (A) PPL image showing the complete replacement of the plagioclase component of a perthite by greisenization, leaving behind patches of sericite (Ser) and skeletal alkali-feldspars (Afs). (B) An XPL image of (A) illustrating the extent of greisenization experienced by the primary mineral assemblage. The relict perthite is outlined in red. (C) A PPL image of a miarolitic cavity within the Lease granite hosting tourmaline (Tur) and doubly terminated quartz (Qz). (D) A PPL image from Type 2 showing the pervasive and destructive tourmalinization of the alkali-feldspars resulting in the growth of radial blue/green tourmaline.

\section{Cassiterite Mineralization}

There are three styles of mineralization within the Zaaiplaats tin fields: disseminated miarolitic zones, tourmalinized-greisenized hydrothermal pipes and lenticular ore bodies. The $600 \mathrm{~m}$ long, 15 to $30 \mathrm{~m}$ wide zones of disseminated mineralization at Groenfontein are hosted within Type 2 Lease granite, 20 to $40 \mathrm{~m}$ below the contact pegmatite. However, at Zaaiplaats mineralization is hosted in both the upper Bobbejaankop and lower Lease granites. Cassiterite in the low-grade disseminated zones occurs in various coexisting styles: (1) free euhedral cassiterite crystals that appear to occur interstitially and to have replaced quartz; (2) sub- to anhedral cassiterite which are associated with the chloritization of biotite and subsequent sericitization of the chlorite; and (3) clusters of euhedral cassiterites within miarolitic cavities $(1$ to $3 \mathrm{~cm}$ ) surrounded by euhedral quartz and red feldspars.

The majority of the cassiterite was mined from an anastomosing network of high-grade greisenized, pipe-like and lenticular ore bodies $[7,11,12,26,27,33]$. The grades of these pipes ranged between $10 \%$ and $70 \%$, with rare occurrences of up to $80 \%$ cassiterite in offshoots. The swarms of hydrothermal pipes radiate upwards through the Bobbejaankop, terminating into lenticular ore bodies in the upper facies of the Lease granite. The pipes shrink from 25 to $3 \mathrm{~m}$ wide in the Bobbejaankop to 5 to $1 \mathrm{~m}$ within the Lease granite. The pipe swarms stem from a single, larger pipe and share a common plunge towards the northwest $[7,13]$. These hydrothermal pipes are composed of three parts: $(1)$ a core of almost pure sericite that contains up to $60 \%$ to $80 \%$ cassiterite $[7,13] ;(2)$ an annular melanocratic zone composed of radial and botryoidal tourmalines, intergrown with anhedral quartz and minor feldspar; and (3) a thin (1 to $5 \mathrm{~cm}$ ) white quartz rim. There is a halo (2 to $15 \mathrm{~cm})$ of highly hematized feldspars and silicification of the surrounding granite.

The lenticular ore-bodies are inaccessible as they were mined out and backfilled but detailed descriptions can be found in Kynaston et al. [34], Söhnge [30], Strauss and Truter [13], and Coetzee [11]. 
These lenses are $5 \mathrm{~m}$ below and contiguous to the contact pegmatite and although similar are distinctly different from the pipes $[7,27,34]$. The main ore grade is recorded between $30 \%$ to $70 \%$ cassiterite hosted in a highly greisenized groundmass composed of sericite, cassiterite, chlorite, fluorite and pyrite similar to the pipes, although distinctly tourmaline-poor $[7,13,34]$. The Lease granite, below these lenses, shows an increased dissemination of fluorite and cassiterite ( $0.5 \%$ to $2 \%)$ that was mined alongside these bodies. In order to determine the petrogenetic relationship between the Lease and Bobbejaankop granite, and to get a better constraint on their formation and mineralization, a number of geochemical analyses were undertaken to complement the petrographic descriptions and contact relationships described.

\section{Methods and Materials}

Whole-rock geochemical analyses were undertaken using the Norrish Fusion [35] technique with in-house correction procedures and using a Panalytical PW2404X-ray fluorescence (XRF) spectrometer at the Earth Lab of the University of the Witwatersrand, Johannesburg (Supplementary Table S1). Samples for XRF majors and ICP-MS traces were prepared and run according to standard procedures using methodology outlined in Wilson [36]. Samples were crushed in a carbon-steel jaw crusher and milled by a carbon-steel swing mill. Major elements were fused using Johnson Matthey Spectrolflux 105 at $1100^{\circ} \mathrm{C}$, and raw data corrected using in-house software. Standard calibrations were made using synthetic oxide mixtures and international standard rocks as well as in-house controls. Calibration standards were primary International Reference Materials USGS series (USA) and NIM series (South Africa). Trace elements were determined using the Perkin Elmer DRC-e inductively coupled plasma mass spectrometer (ICP-MS), and analyzed against certified primary solution standards. International reference materials AGV-2, BCR-1 and BR-1 were analyzed with every run, ensuring the reliability of the data. Of the forty five samples collected in situ, five were of Nebo granite, sixteen of Bobbejaankop granite, twenty of Lease granite, and four of the Transitional Zone. Due to a large degree of overlap, the geochemical data obtained from both the Zaaiplaats and Groenfontein samples are combined under the broader category of "Zaaiplaats tin field". The geochemical data of the samples from their respective mines can be found in Supplementary Table S1. The historical data of the Nebo granite have been compiled from various parts of the Lebowa Granite Suite, while the Bobbejaankop and Lease granites were sampled specifically from the Zaaiplaats tin mine [20,21,28,37].

\section{Results}

Whole Rock XRF and ICP-MS

The granites of the Zaaiplaats tin field have a typical granitic composition, ranging from $\mathrm{SiO}_{2}=74.22 \%$ to $77.35 \%, \mathrm{TiO}_{2}=0.05 \%$ to $0.14 \%, \mathrm{Al}_{2} \mathrm{O}_{3}=10.99 \%$ to $12.85 \%, \mathrm{FeO}^{\text {(tot) }}=0.96 \%$ to $3.95 \%$, with a relatively high alkali content of $\mathrm{Na}_{2} \mathrm{O}=0.90 \%$ to $3.09 \%, \mathrm{~K}_{2} \mathrm{O}=4.57 \%$ to $6.3 \%$, variable $\mathrm{CaO}$ and low $\mathrm{MgO}$ (Figure 12). These ferroan alkali granites exhibit the weakly peraluminous characteristic of A-type granites, with an A/CNK between 0.95 to 1.33, plotting with other global mineralized and unmineralized A-type granites (Figure 13) [38-44].

The trace element differentiation index (TEDI, $(\mathrm{Ba} \times \mathrm{Sr}) / \mathrm{Rb})[1,45]$ has proved to be useful as a fractionation proxy and in distinguishing the various granite facies of the study area (Figure 12). The TEDI defines a progressive fractionation trend from the Nebo, through Bobbejaankop to Lease granite (Figure 12). The major element compositions of the Bobbejaankop and Lease granites are comparable, and distinct in terms of alkali and incompatible element enrichment to the Nebo granite (Figure 12E-G). 

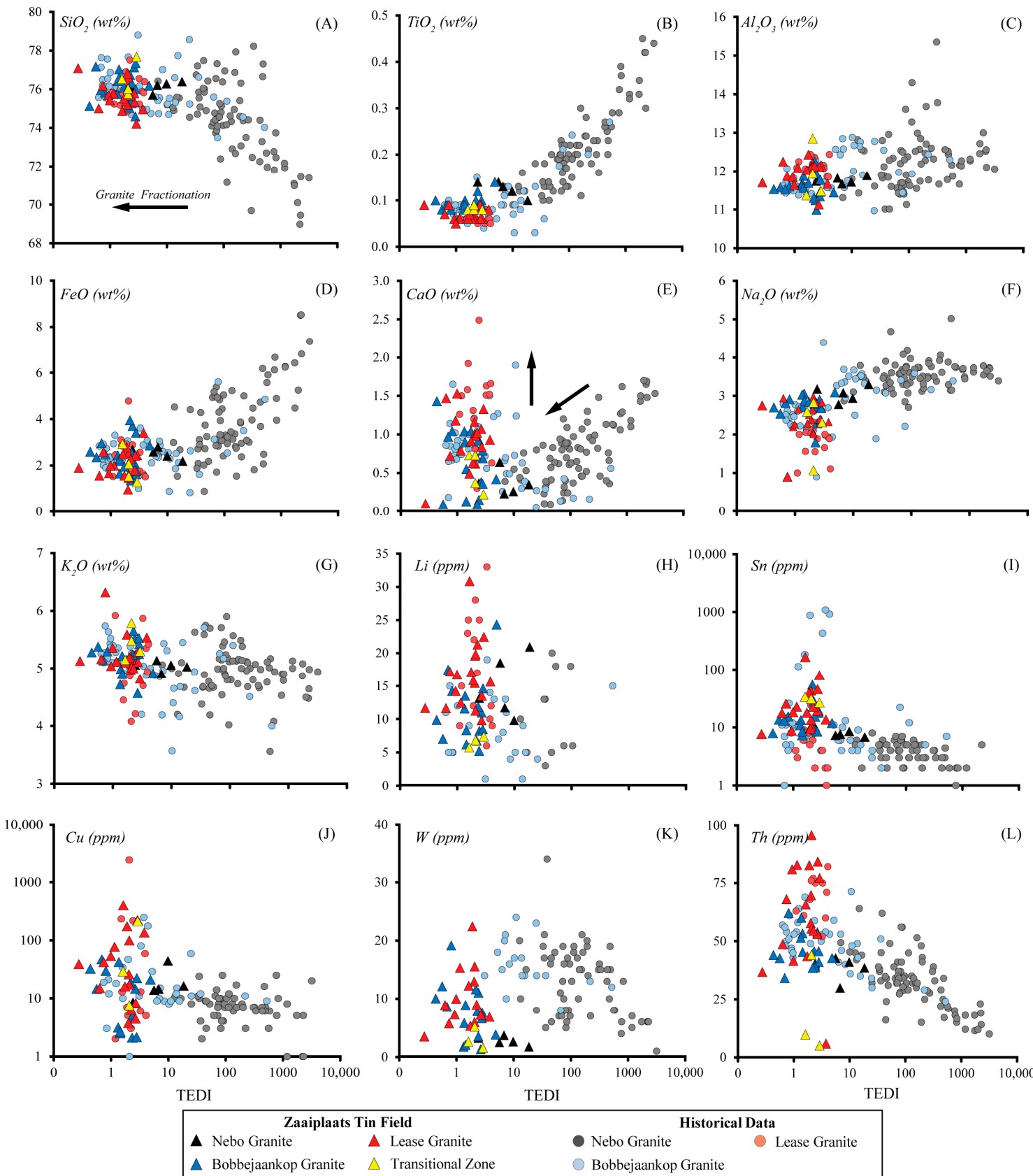

Figure 12. Harker style graphs showing major and trace element distribution within the granites of the Zaaiplaats tin field. The trace element differentiation index (TEDI) by Walraven [45] is used in all graphs. A decrease in TEDI represents an increase in fractionation vs. (A) $\mathrm{SiO}_{2}$ showing an increase from the Nebo to the Lease granite. (B) $\mathrm{TiO}_{2}$ showing a decrease from the Nebo to the Lease granite. (C) $\mathrm{Al}_{2} \mathrm{O}_{3}$ exhibiting a slight decrease from Nebo to Bobbejaankop, however, it does not vary between the Bobbejaankop and Lease granites. (D) $\mathrm{FeO}^{\text {tot }}$ showing a decrease from the Nebo to the Lease granite. (E) $\mathrm{CaO}$ exhibiting a decrease from the Nebo to the Bobbejaankop before increasing in the Lease granite. (F) $\mathrm{Na}_{2} \mathrm{O}$ showing a slight decrease from the Nebo to the Lease granite. (G) $\mathrm{K}_{2} \mathrm{O}$ showing very little variation. (H) Li reveals a distinct increase in the Lease granite. (I) Sn is enriched in the Bobbejaankop and Lease granites. (J) $\mathrm{Cu}$ is relatively consistent apart from the increase in the Lease granite. (K) W showing very little variation. (L) Th increases from the Nebo to the Lease granite. Oxides and elements are in $\mathrm{wt} \%$ and $\mathrm{ppm}$, respectively.

The Bobbejaankop and Lease granites are enriched in $\mathrm{Si}, \mathrm{Li}, \mathrm{Sn}, \mathrm{Cu}$, and Th and depleted in Ti, $\mathrm{Al}$, $\mathrm{Fe}$, and $\mathrm{Na}$ compared to the Nebo granite (Figure 12). The CaO content of the Nebo granite steadily 
decreases with fractionation, compared to the Bobbejaankop and Lease granites, which conversely become more calcic with fractionation (Figure 12E). This is enigmatic, as other alkali elements do not replicate this trend.

Although they are geochemically similar, there are discernible chemical differences between the Lease and Bobbejaankop granites based on their locations, from the mines of Groenfontein or Zaaiplaats. Generally, the granites at Zaaiplaats are more peraluminous and exhibit a greater alkali and incompatible element enrichment than their Groenfontein equivalents. Lithium in the Nebo and Bobbejaankop are similar between $<1$ to $24 \mathrm{ppm}$, although they increase to $30.86 \mathrm{ppm}$ in the Lease granite (Figure 12H). There is a sharp increase in Th from the Nebo to the Lease granite, from 10 to 95.85 ppm, respectively, however, samples from the transitional contact zone appear to be noticeably depleted (Figure 12L). The Sn content of the Bobbejaankop and Lease granites is generally greater than in the Nebo, although certain samples containing disseminated cassiterite have Sn contents greater than 100 ppm and, according to published data, can be as high as 1085 ppm [14] (Figure 12I). The Bobbejaankop granite at Zaaiplaats and the Lease granite at Groenfontein have the highest Sn contents, although Sn at Zaaiplaats is significantly higher. Similarly, $\mathrm{Cu}$ in the Zaaiplaats Bobbejaankop and Lease granites reaches 248 and 2410 ppm, respectively, although comparatively, at Groenfontein, only the Lease granite exhibits a $\mathrm{Cu}$ enrichment of up to $400 \mathrm{ppm}$ (Figure 12J). The transitional zone typically plots between the Bobbejaankop and Lease clusters, but is unusually Th- and Li-depleted.
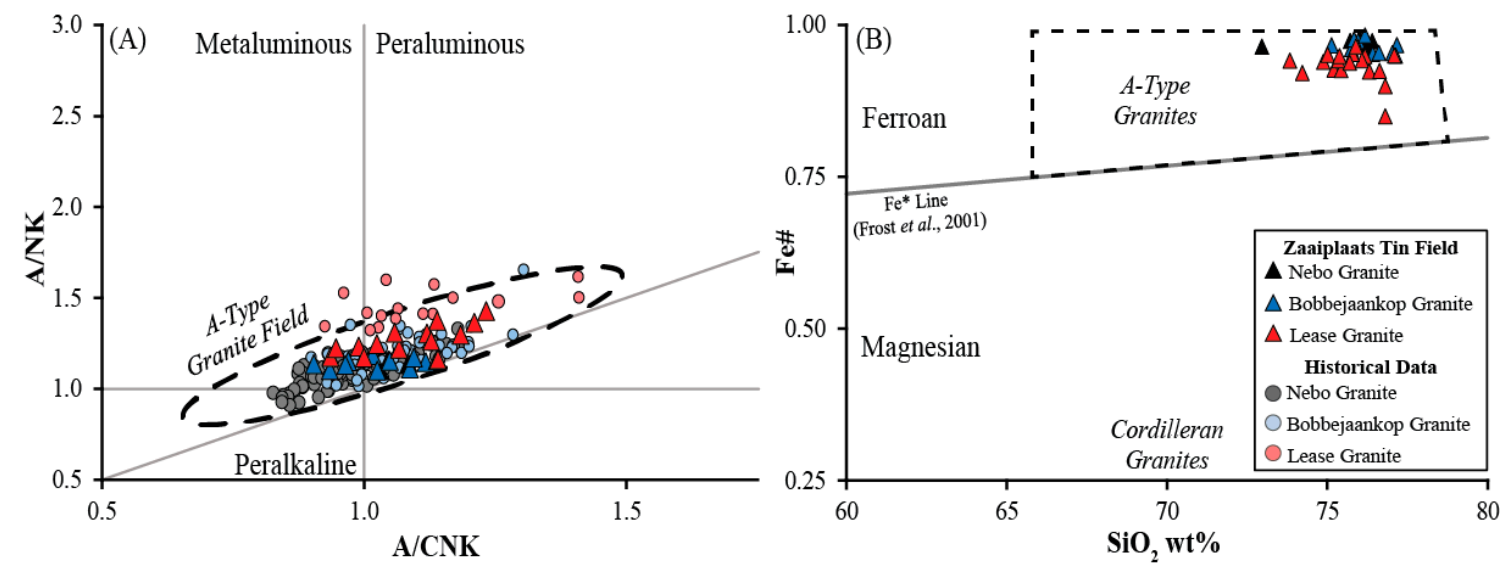

Figure 13. Alumina saturation and ferroan classification diagrams comparing the Zaaiplaats tin field granites with literature data. (A) A/CNK vs. A/NK granite discrimination diagram. The range of global mineralized and unmineralized A-Type granites shown within the dashed ellipse, compiled from published data [38,40-44]. Circular datapoints represent the range of geochemical analyses taken from the literature; Nebo granite (grey), Bobbejaankop granite (blue), and Lease granite (red) [14,20,21,37].

(B) Ferroan classification diagram after Frost et al. [46] displaying the ferroan nature of these granites.

The normative Qz-Or-Ab ternary diagram displays an evolution of these granites from the Nebo, which plots between the hydrous minima of 0.4 and $0.07 \mathrm{H}_{2} \mathrm{O}$ activity $\left(\mathrm{a}_{\mathrm{H} 2 \mathrm{O}}\right)$, towards a more $\mathrm{Qz}>\mathrm{Or}$ composition (Figure 14). The most primitive Nebo granite compositions plot just above the hydrous minimum at $5 \mathrm{~kb}$, and cluster at the $2 \mathrm{~kb}\left(0.5 \mathrm{a}_{\mathrm{H} 2 \mathrm{O}}\right)$ minimum. The majority of the Bobbejaankop and some of the Lease granite compositions cluster along the $2 \mathrm{~kb}$ hydrous cotectic line with an $\mathrm{H}_{2} \mathrm{O}$ activity below 1, and migrate towards the Qz-Or boundary (Figure 14). The Groenfontein granites are more tightly clustered and are not as fractionated as their Zaaiplaats equivalents. 


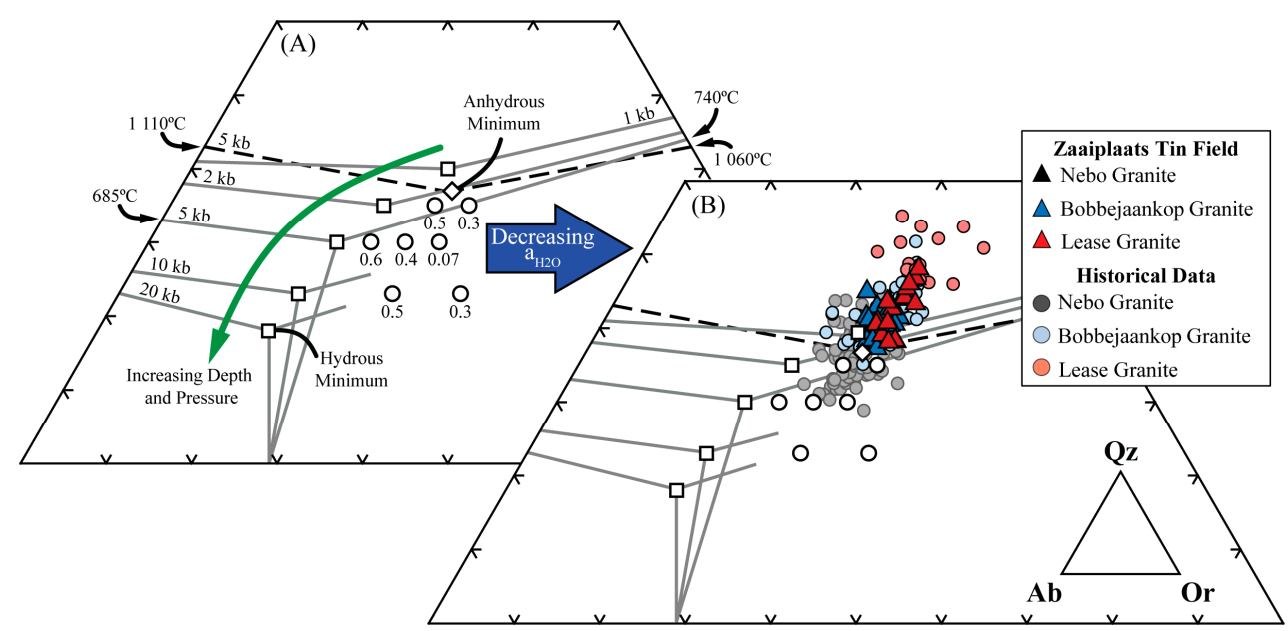

Figure 14. Normative Qz-Ab-Or plot of the granites from the Zaaiplaats tin field (Triangles). (A) White squares and solid lines represent haplogranite, hydrous eutectic points and cotectic lines respectively, which vary due to pressure [47-51]. The white diamond represents the anhydrous minimum [52]. White circles represent the displacement of eutectic points as a function of $\mathrm{H}_{2} \mathrm{O}$ activity $\left(\mathrm{a}_{\mathrm{H} 2 \mathrm{O}}\right)$. (B) Circular datapoints represent the Nebo granite (grey), Bobbejaankop granite (blue) and Lease granite (red) from the literature $[14,20,21,37]$.

The apparent fractionation from the Nebo to Bobbejaankop and then to the Lease granite is demonstrated by ratios such as $\mathrm{Rb} / \mathrm{Sr}$ and TEDI (Figure 15A) [1,45] and can be modelled in terms of Rayleigh Fractionation. A representative assemblage for the Nebo granite of $50 \%$ alkali-feldspar, $30 \%$ quartz, $10 \%$ plagioclase, and $10 \%$ hornblende was used, and the partition coefficients $\left(K_{D}\right)$ for $\mathrm{Rb}, \mathrm{Sr}$, and Ba are given in Supplementary Table S2. The concentration of $\mathrm{Rb}, \mathrm{Sr}$, and Ba within the residual liquid ( $C_{\text {liquid }}$ ) was calculated using Equation (1). The bulk partition coefficient was calculated by multiplying the mineral proportions and the respective $K_{D}$ of $\mathrm{Rb}, \mathrm{Sr}$, and $\mathrm{Ba}$. The $K_{D}$ values for K-feldspar, plagioclase, biotite, hornblende, and quartz are within ranges of published values (Supplementary Table S2) [53-56]. The Nebo granite, in the vicinity of the Zaaiplaats tin field, is considered close to its roof and would inherently be the most evolved Nebo granite facies. Therefore, the initial composition and modal proportions were selected to represent the most primitive facies of the Nebo granite, taken from the literature data $[19,21,37]$.

$$
C_{\text {liquid }}=C_{\text {initial }} \times F^{\left(K_{D}-1\right)}
$$

Rayleigh Fractionation modelling identifies a linear fractionation trend from the Nebo to the Lease granite (Figure 15B). The Nebo granite clusters tightly along the fractionation trend, while the Bobbejaankop and Lease granite data are considerably more scattered. Modelling indicates that $10 \%$ fractionation of the Nebo granite is required to produce the first compositions of the Bobbejaankop granite. After $60 \%$ fractionation, the Nebo granite ends and the Bobbejaankop granite composition becomes dominant (Figure 15B). At approximately $65 \%$ fractionation, the composition of the Lease granite appears and both the Lease and Bobbejaankop granite compositions are present before ending at $80 \%$. Fractionation modelling of the Nebo granite reveals little distinction between the Lease and Bobbejaankop granites. However, elements such as $\mathrm{Rb}, \mathrm{Sr}$, and $\mathrm{Ba}$ may be problematic as they are susceptible to modification by later hydrothermal interaction, so other fractionation ratios are considered. 


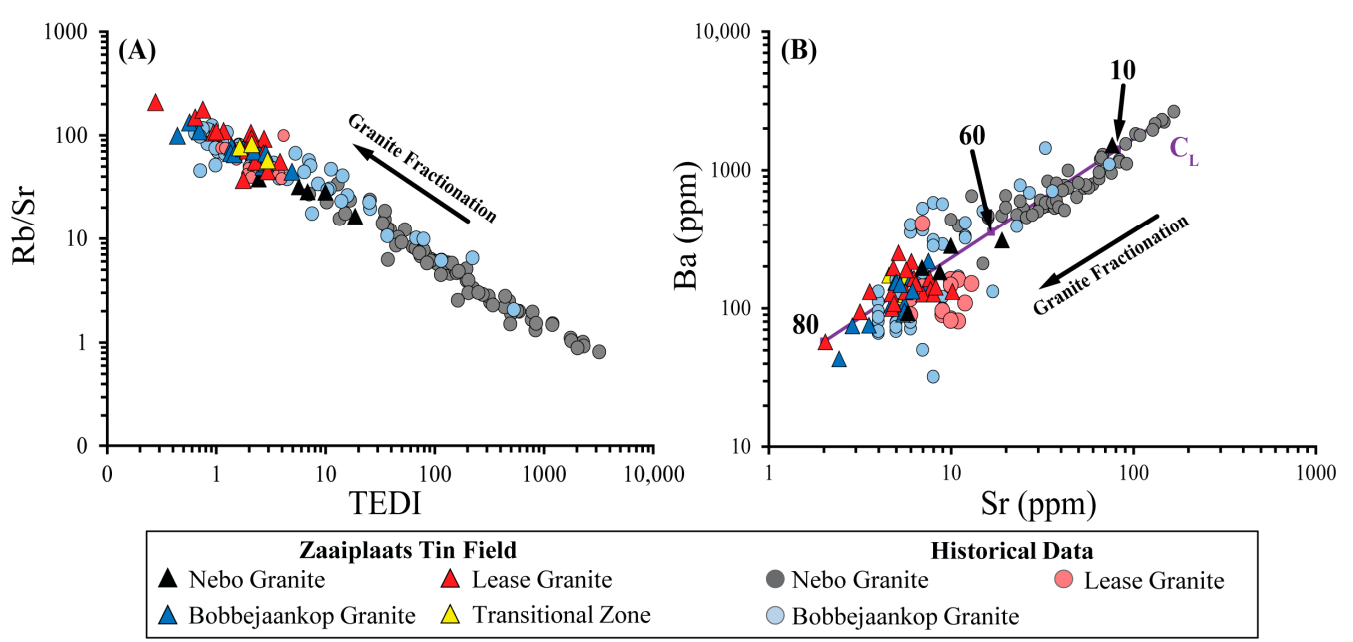

Figure 15. Diagrams illustrating the extent of fractionation of the Zaaiplaats tin field granites, comparing them to the literature data. (A) Plot of TEDI vs. $\mathrm{Rb} / \mathrm{Sr}$ exhibiting the fractionation trend from Nebo (grey) to Lease (red). (B) Rayleigh Fractionation of the Zaaiplaats tin field granites, showing the percentage fractionation along the purple line (Concentration in Liquid, $\mathrm{C}_{\mathrm{L}}$ ). Circular data points represent the range of the literature's geochemical analyses; Nebo granite (grey), Bobbejaankop granite (blue) and Lease granite (red) [14,20,21,37].

The TEDI parameter is able to distinguish the Nebo and Bobbejaankop granites, but is unable to differentiate the Lease from the Bobbejaankop granite. The inferred TEDI fractionation trend is replicated with other, more robust, large ion lithophile element (LILE) ratios such as $\mathrm{Zr} / \mathrm{Hf}$ and $\mathrm{K} / \mathrm{Rb}$, which are regarded as effective indices of granite fractionation [57-61]. These fractionation indices proved more effective in distinguishing between the two granites, although the complete differentiation of the Bobbejaankop and Lease granites was similarly unsuccessful.

Incompatible element ratios such as $\mathrm{Nb} / \mathrm{Ta}$ and $\mathrm{Zr} / \mathrm{Hf}$ are suggested to remain constant within closed, fractionating magmatic systems [59,62,63]. The Lease granite, from Groenfontein and Zaaiplaats, has an average $\mathrm{Zr} / \mathrm{Hf}$ ratio of 18.49 and 20.18, respectively. The Bobbejaankop from Groenfontein and Zaaiplaats shows a higher average $\mathrm{Zr} / \mathrm{Hf}$ of 23.41 and 20.92, respectively, whereas the Nebo granite displays a larger range from 19.74 to 88.57 (Figure 16A). Additionally, comparing Nb/Ta against $\mathrm{Zr} / \mathrm{Hf}$, the Bobbejaankop and Lease granites of Zaaiplaats display a significant decreased $\mathrm{Nb} / \mathrm{Ta}$ ratio compared to the equivalent lithologies from Groenfontein, while maintaining an expected decreasing $\mathrm{Zr} / \mathrm{Hf}$ ratio (Figure 16D). The $\mathrm{Zr} / \mathrm{Hf}$ fractionation proxy shows a progression from the Nebo through Bobbejaankop to Lease granite, as does the TEDI and Rayleigh Fractionation (Figures 15 and 16).

The granites of Zaaiplaats and Groenfontein, although part of the same granitic pluton, exhibit different $\mathrm{Nb} / \mathrm{Ta}$ ratios. The Nebo and Bobbejaankop granites from Groenfontein and Zaaiplaats do not significantly differ in $\mathrm{Nb}$, whereas the Lease granite is considerably enriched (Figure 16A). Moreover, the $\mathrm{Nb} / \mathrm{Ta}$ ratios of the Bobbejaankop and Lease from the two mines, are significantly different (Figure 16B,C). The granites from Groenfontein have a comparatively lower Ta than their counterparts at Zaaiplaats, however the Lease granite is generally more enriched in Ta than the Bobbejaankop granite (Figure 16B,C). Two trends are observed within these granites; the first trend shows an increased Ta of the Groenfontein Lease without variation from the $\mathrm{Nb} / \mathrm{Ta}$ ratio. The second trend exhibited by the Bobbejaankop and Lease from Zaaiplaats shows both an increased Ta content and a deviation in the $\mathrm{Nb} / \mathrm{Ta}$ ratio (Figure 16C).

REE and other trace element patterns display a slight enrichment in light rare earth elements (LREE), a negative Eu anomaly and a plateauing of the heavy rare earth elements (HREE), with high $\mathrm{Zr}, \mathrm{Nb}, \mathrm{Y}, \mathrm{U}, \mathrm{Th}, \mathrm{REE}$ and negative $\mathrm{Ba}, \mathrm{Nb}, \mathrm{Sr}, \mathrm{P}$, Ti and Eu anomalies, consistent with typical A-types (Figure 17) [20,38,64-67]. There is little separation between the granites apart from the enrichment of incompatible and mobile elements such as Rb, Ba, Th, U, Sr, P, Sn and HREEs in the Lease granite 
(Figure 17B). The transitional zone, however, exhibits an atypical trend compared to the other granites. With the exception of one sample that plots similarly to the Bobbejaankop granite, the transitional zone is significantly REE-, Ce-, La-, Th-, Sm- and U-depleted (Figure 17A,B).
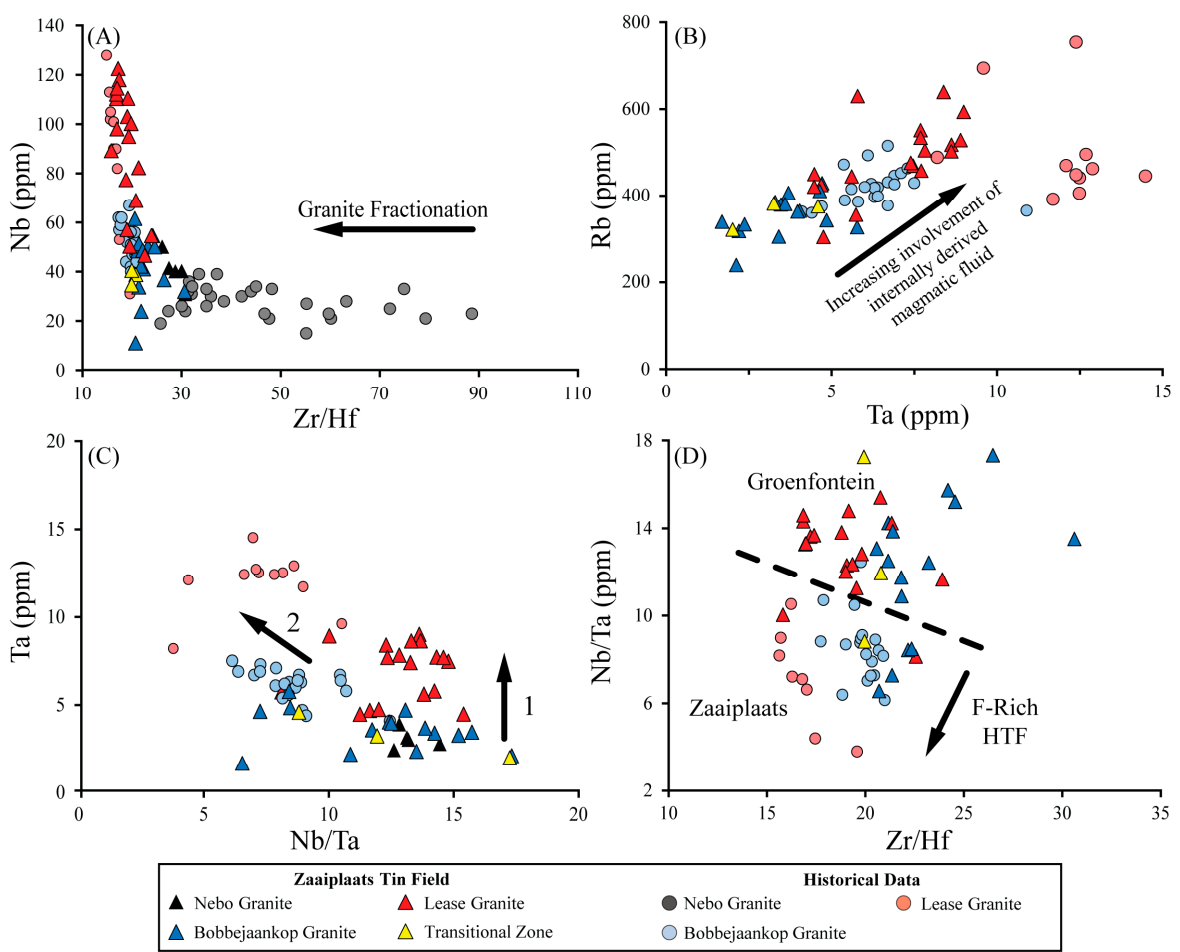

Figure 16. Diagrams illustrating the LILEs and different indexes of fractionation from the Zaaiplaats tin field granites (A) Graph of $\mathrm{Zr} / \mathrm{Hf}$ vs. $\mathrm{Nb}$ indicating an increasing $\mathrm{Nb}$ with decreased $\mathrm{Zr} / \mathrm{Hf}$. (B) Plot of $\mathrm{Ta}$ vs. $\mathrm{Rb}$ that represents the geochemical signature of internally derived magmatic fluids, displaying a spectrum of increasing hydrothermal activity of the Bobbejaankop and Lease granites from Groenfontein and Zaaiplaats. (C) The Nb/Ta vs. Ta graph shows two trends: (1) increased Ta without variation in the $\mathrm{Nb} / \mathrm{Ta}$ ratio; and (2) increase in Ta with deviation in the $\mathrm{Nb} / \mathrm{Ta}$ ratio. (D) The $\mathrm{Zr} / \mathrm{Hf} \mathrm{vs} . \mathrm{Nb} / \mathrm{Ta}$ graph highlights the decoupling of the $\mathrm{Nb} / \mathrm{Ta}$ magmatic signature producing two different ratios for the Bobbejaankop and Lease granites (dashed line) caused by F-rich hydrothermal fluids (HTF). Circular datapoints represent the range of the literature geochemical analyses; Nebo granite (grey), Bobbejaankop granite (blue) and Lease granite (red) $[14,20,21,37]$.

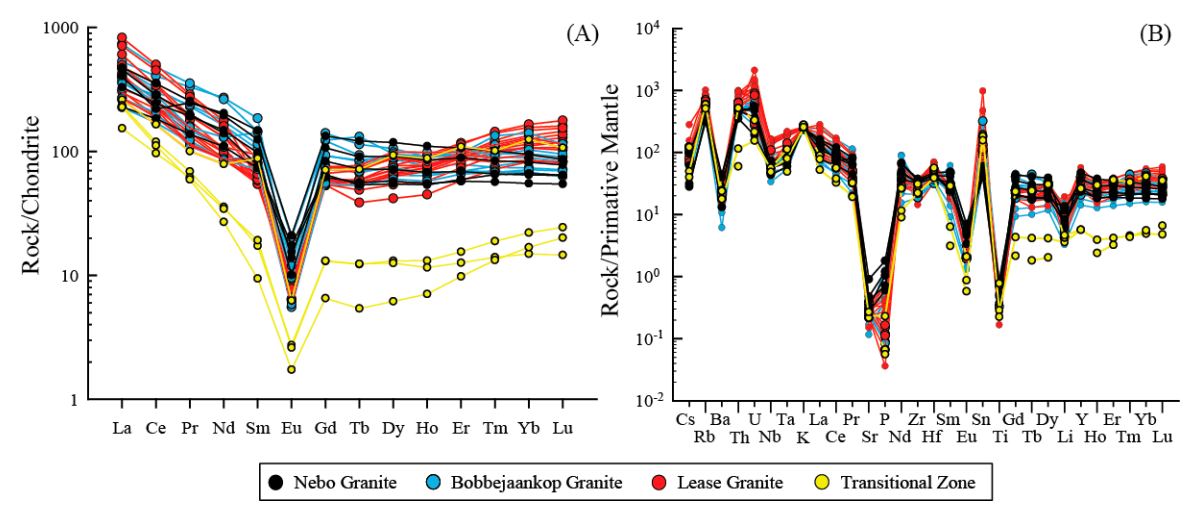

Figure 17. Rare earth element (REE) and multi-element diagrams of the granites from the Zaaiplaats tin field (A) Chondrite-normalized REE patterns for the Nebo, Bobbejaankop and Lease granites. Values normalized using data from McDonough and Sun [68]. (B) Primitive mantle-normalized multielement patterns for the Nebo, Bobbejaankop and Lease granites. Normalized using values from Sun and McDonough [69]. 


\section{Discussion}

The mineralogical evolution of the Nebo granite, from its hornblende-bearing base to the biotite-bearing roof, suggests in situ fractionation of the granite [4,20-24]. Therefore, it is sensible to suggest that the gradual evolution from the Nebo to the Bobbejaankop granite would represent a continuation of this fractionation trend. Trace element fractionation proxies and Rayleigh Fractionation display a linear trend from the Nebo to the Bobbejaankop and Lease granites, supporting the origin of the Bobbejaankop by fractionation of the Nebo granite (Figure 15). Rayleigh Fractionation shows the Lease and Bobbejaankop granites to be the upper limit of what can be considered a reasonable degree of fractionation (Figure 15B). However, taking the relative scales of these plutonic bodies into account, the degree of fractionation is not as unrealistic as initially thought. The Nebo granite has an approximate volume of $100,000 \mathrm{~km}^{3}$ and is internally fractionated [70]. Thus, as the Bobbejaankop granite is only several hundred meters thick, approximately $65 \%$ fractionation of the Nebo granite is probable $[20,70]$. However, the inability to geochemically distinguish between the Bobbejaankop and Lease granites, using fractionation ratios suggests that fractionation alone is not responsible for the formation of Lease granite.

Petrographically, the differences between the Bobbejaankop and the Lease granite are granophyric grain-size reduction and increased microclinization, chloritization, and sericitization (Figures 7 and 13A). Geochemically the differences are more subtle, mainly pertaining to increased incompatible and large ion lithophile elements, such as $\mathrm{Ce}, \mathrm{Cs}, \mathrm{Cu}, \mathrm{Li}, \mathrm{Lu}, \mathrm{Nb}, \mathrm{Rb}, \mathrm{Sn} \mathrm{Ta}, \mathrm{Th}, \mathrm{U}$, and $\mathrm{Yb}$ (Figure 17). These elements are readily mobilized by hydrothermal fluids and, as there was no exogranitic fluid escape [28], can be inferred to represent the accumulation of late-stage fractionated hydrothermal fluids. The increased calcium content of the Lease compared to the Bobbejaankop granite is seen by the increased presence of fluorite and epidotization of the plagioclase. Chloritization, the dominant alteration within the Bobbejaankop granite, becomes increasingly subordinate to microclinization, sericitization, and occasionally epidotization within the Lease granite. A geochemical representation of this shift in alteration is proxied by $\left(\mathrm{K}_{2} \mathrm{O}+\mathrm{CaO}\right) / \mathrm{Na}_{2} \mathrm{O}$, where an increased ratio represents a corresponding increase in microclinization $(\mathrm{K})$ and epidotization $(\mathrm{Ca})$ and the loss of Na-plagioclase. The Na depletion, is the result of the breakdown of plagioclase and the loss of $\mathrm{Na}$, which resulted from more intense greisenization particularly apparent within the Type 3 Lease (Figures 11B and 12F) [71-73]. Generally, $\left(\mathrm{K}_{2} \mathrm{O}+\mathrm{CaO}\right) / \mathrm{Na}_{2} \mathrm{O}$ increases from the Nebo to the Bobbejaankop granite, however, the Lease granite at Zaaiplaats is significantly more altered (Figure 18A). Similarly the migration of the data for the Lease granites, on the Qz-Ab-Or diagram, away from the Nebo and Bobbejaankop clusters suggests that the Lease experienced a greater degree of microclinization and greisenization (Figure 14) [18]. Furthermore, by combining the feldspar alteration proxy with a biotite chloritization proxy $\mathrm{TiO}_{2} / \mathrm{FeO}^{\text {(tot) }}$ [73], a shift in the dominant style of hydrothermal alteration is identified (Figure 18B). Additionally, combining alteration with $\mathrm{Sn}$ content reveals a concentration of $\mathrm{Sn}$ at the transition from chloritization to microclinization and epidotization as the dominant styles of alteration (Figure 18B). Therefore, the highest $\mathrm{Sn}$ grade, at both mines coincides with the change in alteration from chloritization to microclinization and epidotization (Figure 18B). Mineralized granites from both mines occur at this transition between alterations, suggesting a "goldilocks" region of alteration. Moreover, it appears that the disseminated mineralization is not associated with specific lithologies, but is rather dependent on the dominant style of hydrothermal alteration.

The contact between the Bobbejaankop and Lease granites is not as sharp as previously described $[7,11,26,27]$. The shift from an unaltered Bobbejaankop through a transitional contact zone is defined by the incipient and selective alteration of feldspars and granophyric grain-size reduction. This develops a texture that is intermediate between that of the Bobbejaankop and Lease granites (Figure 7). Geochemically, this transition zone is marked by a distinct REE and incompatible element depletion, suggesting that before being depleted and incompletely altered to Lease granite, this zone was originally typical Bobbejaankop granite (Figures 12 and 17). 


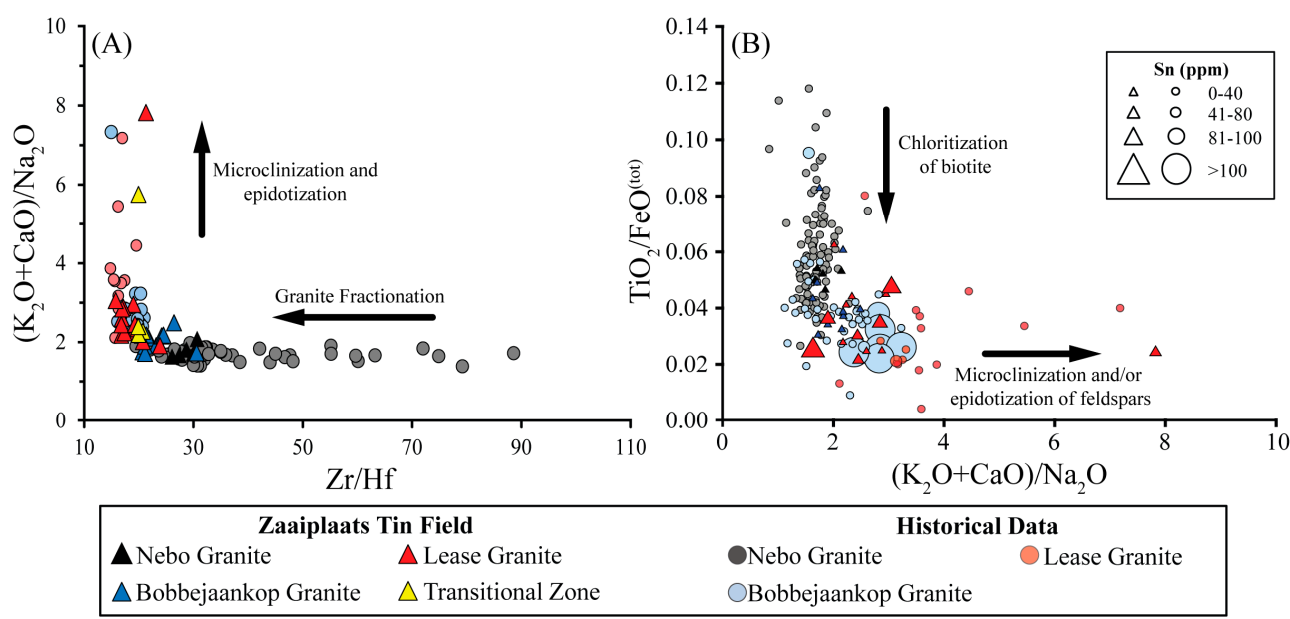

Figure 18. Diagrams showing the various alteration proxies and their correlation with $\mathrm{Sn}$ in the Zaaiplaats tin field granites (A) Graph of $\mathrm{Zr} / \mathrm{Hf}$ vs. $\left(\mathrm{K}_{2} \mathrm{O}+\mathrm{CaO}\right) / \mathrm{Na}_{2} \mathrm{O}$ indicate the increase in microclinization and epidotization in the highly fractionated granite phases. (B) Graph of $\left(\mathrm{K}_{2} \mathrm{O}+\mathrm{CaO}\right) /$ $\mathrm{Na}_{2} \mathrm{O}$ vs. $\mathrm{TiO}_{2} / \mathrm{FeO}^{\text {(tot) }}$ describing the dominant style of hydrothermal alteration. Scaling of the symbols represents the concentration of $\mathrm{Sn}(\mathrm{ppm})$ within the samples. Circular datapoints represent the range of the literature's geochemical analyses; Nebo granite (grey), Bobbejaankop granite (blue) and Lease granite (red) [14,20,21,37].

Where present, the transitional zone at Groenfontein is several centimetres thick, however at Zaaiplaats the transitional zone reaches up to $4 \mathrm{~m}$ wide. This is explained by a combination of factors; first the downward migrating of a dynamic alteration front which, as fluid accumulated in the cupola, prograded downwards into the Bobbejaankop magma, stripping mobile elements before regressing. The transitional zone represents a region where the alteration front regressed before completing the alteration of the Bobbejaankop granite. Secondly, the variability in the permeability of the Bobbejaankop mush, controlled by the degree of crystallization, would have variably facilitated or inhibited the infiltration of the hydrothermal fluids. This would have resulted in gradational or sharp contacts, where the permeability was either high or low, respectively.

The geochemical decoupling of incompatible elements between the Lease and Bobbejaankop granites from the two mines is due to an increased hydrothermal signature at Zaaiplaats, suggesting a greater accumulation of hydrothermal fluids towards the Zaaiplaats end of the pluton (Figure 16).

Incompatible $\mathrm{Zr}$ and $\mathrm{Hf}$ are concentrated in a silicic magmas at a constant ratio, although the crystallization of zircon decreases the $\mathrm{Zr} / \mathrm{Hf}$ ratio and which then can be used to monitor the evolution of granitic magmas [61,74-76]. This is evident in the consistent $\mathrm{Zr} / \mathrm{Hf}$ decrease from the Nebo through Bobbejaankop to the Lease granite at both Groenfontein and Zaaiplaats. A decrease in $\mathrm{Zr} / \mathrm{Hf}$ below 30 has also been linked to the enrichment of LILE and HFSE such as $\mathrm{Sn}, \mathrm{W}, \mathrm{Mo}, \mathrm{Ta}, \mathrm{Nb}, \mathrm{Li}, \mathrm{Zr}$ and Hf, to the point of economic viability [61,74-76]. The Lease and Bobbejaankop granites, unsurprisingly, have $\mathrm{Zr} / \mathrm{Hf}$ ratios between 15 and 30, which correspond to greisen related Sn-W-Mo-Be deposits, whereas the unmineralized Nebo granite has a $\mathrm{Zr} / \mathrm{Hf}$ ratio higher than $30[61,74,76]$.

Similarly, the $\mathrm{Nb} / \mathrm{Ta}$ parameter is used as an index of fractionation as the ratios should remain broadly similar in an evolving magmatic system [59-63,74-77]. However, an increase in Ta (decrease in $\mathrm{Nb} / \mathrm{Ta}$ ) is attributed to the involvement of fluorine-rich, autometasomatic, mineralizing and greisenizing fluids [59-63,77]. The Bobbejaankop and Lease granites deviate from the $\mathrm{Nb} / \mathrm{Ta}$ ratio of the Nebo, displaying an enrichment of Ta, particularly at Zaaiplaats (Figure 16). The deviation from the magmatic $\mathrm{Nb} / \mathrm{Ta}$ ratio is attributed to increased interaction with internally derived magmatic fluids. The correlation of incompatible elements such as Ta vs. $\mathrm{Rb}$, suggest the involvement of such internally derived magmatic fluid prior to greisenization (Figure 16B) [61,78]. The deviation from the magmatic $\mathrm{Nb} / \mathrm{Ta}$ ratio highlights a transition from a magmatically dominated, to an F-rich, 
magmatic-hydrothermal dominant environment (Figure 16D). Therefore, the main difference between the granites of the two mines is the increased accumulation and influence of pre-greisenization, F-rich magmatic-hydrothermal fluids at Zaaiplaats.

These fluids have been shown to be $\mathrm{CO}_{2}$-bearing and hypersaline, containing $\mathrm{KCl}, \mathrm{NaCl}$, and $\mathrm{FeCl}$ [28]. Thus, coupled with the abundance of hematite and fluorite, it is reasonable to suggest these granites were altered by an extremely, $\mathrm{F}^{-}, \mathrm{Cl}^{-}$, and Fe-rich fluid [28,79]. The presence of $\mathrm{Cl}^{-}$and $\mathrm{CO}_{2}$ within granitic magmas enhanced the complexation and mobility of HREEs in the magmatically-derived hydrothermal fluids, as well as reducing the activity of $\mathrm{H}_{2} \mathrm{O}$, as evident in the low $\mathrm{H}_{2} \mathrm{O}$ activity shown in Figure 14B. However, the anomalous $\mathrm{Cu}$ enrichment within the Lease granite may be related to the exsolution of an aqueous fluid phase. The mobility and concentration of $\mathrm{Cu}$ in hydrothermal fluids is largely a function of the salinity of the aqueous fluid because the solubility of a likely $\mathrm{CuCl}_{2}$ complex is proportional to the $\mathrm{Cl}^{-}$concentration of the fluid [80,81]. As the granites of the Zaaiplaats tin field are thought to have intruded at approximately 4 to $5 \mathrm{~km}$ depth, it is very likely that the magmas underwent fluid saturation as evident in the abundant manifestations of magmatic-hydrothermal alteration and mineralization described herein $[15,28,82]$. This would have occurred at around 1 to $2 \mathrm{~kb}$ of pressure, as shown in Figure 14 and assuming a $0.3 \mathrm{~kb} / \mathrm{km}$ pressure gradient in the continental crust (after Winter [83]).

Evidence for fluid saturation, by decompression of the crystallizing magma, is provided by the abundant miarolitic cavities. Fluid saturation may have been caused by continuous crystallization and/or decompression of the magma. The decreasing volume, caused by crystallization, may have led to shrinking of the volume occupied by the magma and partial detachment from the roof, allowing the formation of the marginal pegmatitic zone. The abundance of hematized feldspars, suggests a relatively oxidizing environment, which could have been achieved by fluid mixing or boiling [81,84,85]. Pollard et al. [28] showed that these granites evolved in a closed system with little to no external influence, thus oxidation via boiling is the most likely mechanism. Furthermore, the abundance of fluorite and particularly tourmaline within the Lease granite would suggest a reasonable amount of $\mathrm{F}$ and $\mathrm{B}$ within the fluid. During the exsolution of a vapor-rich fluid, these volatiles would have preferentially partitioned into the vapor phase, therefore, together with the coexisting brine, they were transported and accumulated into the granite cupola.

The solubility of metals improves with increasing volatile concentration and acidity, facilitating their transportation within these magmatic-hydrothermal fluids [81,86-89]. Thus, internally derived magmatic fluid, produced by the crystallizing Bobbejaankop granite, would have become enriched in various metals, such as $\mathrm{Fe}, \mathrm{Al}$, and $\mathrm{Sn}$. Such fluids would have had the ability to concentrate and transport significant concentrations of Sn, however they would not necessarily have precipitated cassiterite. During fluid saturation, Sn preferentially partitions into the aqueous phase, possibly as a $\mathrm{SnCl}_{2}$ complex in a relatively saline, acidic fluid $[85,87,90]$. Therefore, the loss of $\mathrm{H}, \mathrm{F}$, and B into a vapor phase, would have simultaneously buffered and oxidized the aqueous phase, precipitating $\mathrm{SnO}_{2}[85,87,90]$. The process of neutralization-induced greisenization of the surrounding granite caused the decomposition of feldspars and precipitation of cassiterite. Cassiterite mineralization, where present within the hydrothermal pipes, is concentrated within the sericitized core, and partially within the surrounding melanocratic tourmaline-rich layer. Similarly, miarolitic and pod-like mineralization within the Lease granite is associated with the greisenized decomposition of feldspars. The disseminated mineralization within the Bobbejaankop granite was the result of the neutralization of the Sn-rich aqueous phase, while the B- and F-rich fluid accumulated in the roof. Thus, the Lease granite is proposed to be the altered product of a semi-crystallized Bobbejaankop magma, by the saturation and accumulation of a magmatic-hydrothermal acidic, saline-rich fluid. Therefore, the Lease granite represents the transition from a magmatic to a magmatic-hydrothermal dominant system. 


\section{Formation of the Lease and Bobbejaankop Granites}

The results of this study strongly support the formation of the Bobbejaankop granite by fractionation of the Nebo granite. The linear trend displayed by the normative Qz-Ab-Or diagram suggests that the Lease granite is neither a separate intrusion nor a chilled margin of the Bobbejaankop granite (Figure 14). Rather, it suggests that the Lease granite gradually evolved in the cupola of the Bobbejaankop mush by fluid saturation and subsequent hydrothermal alteration.

The extensive microclinization and reordering of the Bobbejaankop feldspars increased their porosity, allowing pervasive fluid movement [32,91]. The inward crystallization of the Bobbejaankop granite would have concentrated LILE and incompatibles into a late-stage, acidic, and F-rich autometasomatic magmatic-hydrothermal fluid. Eventual fluid exsolution and the porosity of the feldspars facilitated the upwards migration and accumulation of the fluids in the upper facies of the Bobbejaankop mush. The gradual effervescence and fluid saturation produced ubiquitous miarolitic cavities and the subsequent precipitation of cassiterite within them. The migration and accumulation of these volatile-rich bubbles would have concentrated B, F, H, and $\mathrm{Cu}$ in the granite cupola.

The process of devolatilization and bubble migration is referred to as the "bubble laden plume theory" and was proposed by Candela [92]. This model describes the formation of boron, alkali-, and metal-rich bubbles that migrated upwards through a crystallizing granitic magma, accumulating in the roof. At low degrees of crystallization, these bubbles would have coalesced and formed large, bubble-laden plumes that streamed through conduits in the semi-crystalline mush. Granitic systems, such as Zaaiplaats, that have significant concentrations of Li, B, F, and $\mathrm{H}$ will have a higher diffusivity, greater $\mathrm{H}_{2} \mathrm{O}$ solubility, and lower viscosity, facilitating the migration of bubbles and increasing permeability for pervasively altering fluids [92-94]. Some of the hydrothermal pipes have large central cavities or voids, surrounded by a melanocratic zone of tourmaline-quartz. Thus, they may represent large bubble-laden plumes, formed by the accumulation and channeling of these exsolved greisenizing volatile and metal-rich fluids. The alumina required for the formation of the aluminosilicates within the pipes and Lease granite were sourced from the decomposition of feldspars by greisenization [87,94-96]. Thus, the neutralization of Sn-bearing fluids within the pipes explains the high-grade deposition of cassiterite within the sericitized cores.

The accumulation of these fluids resulted in the complete alteration of the Bobbejaankop granite and the formation of various types of Lease granite. The transitional zone, regarded as the contact between the granites, represents a region of incomplete alteration of the Bobbejaankop granite. A possible combination of the topographic variations in the roof of the Bobbejaankop magma chamber, convection, porosity, and microstructure, channeled the fluids towards Zaaiplaats. Therefore, the peripheral Lease microgranite is the result of a magmatically derived hydrothermal fluid alteration in the semi-crystallized Bobbejaankop granite cupola.

\section{Conclusions}

The meta- and peraluminous, ferroan granites of the Zaaiplaats tin field, exhibit the typical characteristics of A-Type granitoids. Trace element geochemistry indicates that the Bobbejaankop granite resulted from extensive fractionation of the Nebo granite, whereas the Lease granite represents the hydrothermal alteration of the semi-crystallized Bobbejaankop magmatic mush by an incompatible element rich, acidic, magmatically derived hydrothermal fluid. Incipient microclinization and chloritization, followed by a pervasive and destructive style of alteration, resulted in the fine-grained Lease in the roof of the Bobbejaankop granite. The textural and mineralogical variants in the Lease granite were dependent on the extent and dominant style of hydrothermal alteration. Fluid saturation mobilized and concentrated volatiles and incompatible elements, resulting in the ubiquitous tourmalinization and greisenization within the Lease granite. The coalescence and migration of the magmatically-derived hydrothermal fluids resulted in the formation of large tourmaline-quartz hydrothermal pipes. Neutralization of the Sn-bearing hydrothermal fluids precipitated cassiterite within miarolitic cavities, and hydrothermal pipes within the Lease and upper portions of the 
Bobbejaankop granite. Therefore, the Lease microgranite represents the alteration in the cupola of the semi-crystalline Bobbejaankop granite, by the accumulation of internally derived metal and volatile-rich magmatic-hydrothermal fluids.

Supplementary Materials: The following are available online at http://www.mdpi.com/2075-163X/10/4/379/s1, Table S1: Complete list of whole rock XRF and ICP-MS results of the sampled Zaaiplaats tin field granites; Table S2: Partition coefficients $\left(K_{D}\right)$ and representative modal proportions of the Nebo granite used in Rayleigh Fractionation calculations.

Author Contributions: Conceptualization, Investigation, and Writing—original draft, L.V.; Project administration, Supervision, Writing-review and editing, and assistance in field investigations, P.N., J.K. and L.R. All authors have read and agree to the published version of the manuscript.

Funding: This research was funding by THRIP (Technology and Human Resources for Industry Programme) (001.410.8755101.5121105) under project TP14082193395-Mineralisation Processes in the Bushveld Complex.

Acknowledgments: We would also like to acknowledge the support of VM Investment Co. and Simon Nethononda of Bushveld Minerals who assisted in field expeditions, provided access to the various mines, and for graciously providing accommodation for the duration of the field seasons. The Earth Lab at the University of the Witwatersrand is thanked for analyzing whole-rock major and trace elements by XRF and ICP-MS.

Conflicts of Interest: The funders had no role in the design of the study; in the collection, analyses, or interpretation of data; in the writing of the manuscript, or in the decision to publish the results.

\section{References}

1. Bailie, R.H.; Robb, L.J. Polymetallic mineralization in the granites of the Bushveld Complex-Examples from the central southeastern lobe. S. Afr. J. Geol. 2004, 107, 633-652. [CrossRef]

2. Finn, C.A.; Bedrosian, P.A.; Cole, J.C.; Khoza, T.D.; Webb, S.J. Mapping the 3D extent of the Northern Lobe of the Bushveld layered mafic intrusion from geophysical data. Precambrian Res. 2015, 268, 279-294. [CrossRef]

3. Zeh, A.; Ovtcharova, M.; Wilson, A.H.; Schaltegger, U. The Bushveld Complex was emplaced and cooled in less than one million years-Results of zirconology, and geotectonic implications. Earth Planet. Sci. Lett. 2015, 418, 103-114. [CrossRef]

4. Kinnaird, J.A.; Kruger, F.J.; Cawthorn, R.G. Rb-Sr and Nd-Sm isotopes in fluorite related to the granites of the Bushveld Complex. S. Afr. J. Geol. 2004, 107, 413-430. [CrossRef]

5. Zeh, A.; Allan, H.W.; Gudelius, D.; Gerdes, A. Hafnium isotopic composition of the Bushveld Complex requires mantle melt-upper crust mixing: New evidence from zirconology of mafic, felsic and metasedimentary rocks. J. Petrol. 2020. [CrossRef]

6. Robb, L.J.; Freeman, L.A.; Armstrong, R.A. Nature and longevity of hydrothermal fluid flow and mineralisation in granites of the Bushveld Complex, South Africa. Earth Sci. 2000, 91, 269-281.

7. Crocker, I.T.; Eales, H.V.; Ehlers, D.L. The Fluorite, Cassiterite and Sulphide Deposits Associated with the Acid Rocks of the Bushveld Complex; Council for Geoscience: Pretoria, South Africa, 2001; p. 151.

8. De Waal, S.A. The Bushveld granites in the Zaaiplaats area. Trans. Geol. Soc. S. Afr. 1972, 75, 135-143.

9. Lenthall, D.H.; Hunter, D.R. The geochemistry of the Bushveld granites in the Potgietersrus tin-field. Precambrian Res. 1977, 5, 359-400. [CrossRef]

10. Falcon, L.M. Tin in South Africa. J. S. Afr. Inst. Min. Metall. 1985, 85, 333-345.

11. Coetzee, J. A Geochemical and Petrographical Investigation of the Low-Grade Tin Deposits in the Bobbejaankop Granite at the Zaaiplaats Tin Mine. 1984. Available online: https://repository.up.ac.za/ handle/2263/60909 (accessed on 15 April 2020).

12. Coetzee, J.; Twist, D. Disseminated tin mineralisation in the roof of the Bushveld granite pluton at the Zaaiplaats mine, with implications for the genesis of magmatic hydrothermal tin systems. Econ. Geol. 1989, 84, 1817-1834. [CrossRef]

13. Strauss, C.A.; Truter, F.C. The Bushveld granites in the Zaaiplaats tin mining area. Trans. Geol. Soc. S. Afr. 1944, 47, 47-77.

14. Pollard, P.J.; Taylor, R.G.; Taylor, R.P.; Groves, D.I. Petrographic and geochemical evolution of pervasively altered Bushveld granites at the Zaaiplaats tin mine. Econ. Geol. 1991, 88, 1401-1453. [CrossRef] 
15. Gruenewaldt, G.V.; Strydom, J.H. Geochemical distribution patterns surrounding tin-bearing pipes and the origin of the mineralizing fluids at the Zaaiplaats tin mine, Potgietersrus district. Econ. Geol. 1985, 80, 1201-1211. [CrossRef]

16. Pollard, P.J.; Taylor, R.G.; Tate, N.M. Textural evidence for quartz and feldspar dissolution as a mechanism of formation for Maggs Pipe, Zaaiplaats tin mine, South Africa. Miner. Depos. 1989, 24, 210-218. [CrossRef]

17. Hunter, D.R. The Regional Geological Setting of the Bushveld Complex (An Adjunct to the Provisional Tectonic Map of the Bushveld Complex); Economic Geology Research Unit, University of the Witwatersrand: Johannesburg, South Africa, 1975; p. 18.

18. Hunt, J.P. Geological Characteristics of Iron-Oxide-Copper-Gold (IOCG) Type Mineralisation in the Western Bushveld Complex; University of the Witwatersrand: Johannesburg, South Africa, 2005.

19. Kleemann, G.J. The Geochemistry and Petrology of the Roofrocks of the Bushveld Complex East of Groblersdal. Master's Thesis, University of Pretoria, Pretoria, South Africa, 1985.

20. Kleemann, G.J.; Twist, D. The compositionally-zoned sheet-like granite pluton of the Bushveld Complex: Evidence bearing on the nature of a-type magmatism. J. Petrol. 1989, 30, 1383-1414. [CrossRef]

21. Hill, M.; Barker, F.; Hunter, D.; Knight, R. Geochemical characteristics and origin of the Lebowa Granite Suite, Bushveld Complex. Int. Geol. Rev. 1996, 38, 195-227. [CrossRef]

22. Wilson, J.; Ferre, E.C.; Lespinasse, P. Repeated tabular injection of high-level alkaline granites in the eastern Bushveld, South Africa. J. Geol. Soc. 2000, 157, 1077-1088. [CrossRef]

23. McCarthy, T.S.; Fripp, R.E.P. The crystallization history of a granitic magma, as revealed by trace element abundances. J. Geol. 1980, 88, 211-224. [CrossRef]

24. McNaughton, N.J.; Pollard, P.J.; Groves, D.I.; Taylor, R.G. A long-lived hydrothermal system in Bushveld granites at the Zaaiplaats tin mine: Lead isotope evidence. Econ. Geol. 1993, 88, 27-43. [CrossRef]

25. Pollard, P.J.; Taylor, R.G. Progressive evolution of alteration and tin mineralisation: Controls by interstitial permeability and fracture-related tapping of magmatic fluid reservoirs in tin granites. Econ. Geol. 1986, 81, 1795-1800. [CrossRef]

26. Coetzee, J. The Lease granite-A granophyric, miarolitic mineralised granite at the apical region of a tin-tungsten system. Trans. Geol. Soc. S. Afr. 1986, 89, 335-345.

27. Strauss, C.A. The geology and mineral deposits of the Potgietersrus tinfields. S. Afr. Geol. Surv. Mem. 1954, 46, 241.

28. Pollard, P.J.; Andrew, A.S.; Taylor, R.G. Fluid inclusion and stable isotope evidence for interaction between granites and magmatic hydrothermal fluids during formation of disseminated and pipe-style mineralization at the Zaaiplaats tin mine. Econ. Geol. 1991, 86, 121-141. [CrossRef]

29. SACS. Stratigraphy of South Africa. Part 1 (Kent, L.E. Comp.), Lithostratigraphy of the Republic of South Africa. In Stratigraphy of South Africa Handbook; Government Printer: Pretoria, South Africa, 1980; Volume 8, p. 690.

30. Söhnge, P.G. The structure, ore genesis and mineral sequence of the cassiterite deposit in the Zaaiplaats tin mine, Potgietersrust district, Transvaal. Trans. Geol. Soc. S. Afr. 1944, 47, 157-181.

31. Putnis, A. Mineral replacement reactions: From macroscopic observations to microscopic mechanisms. Mineral. Mag. 2002, 66, 689-708. [CrossRef]

32. Putnis, A.; Hinrichs, R.; Putnis, C.V.; Golla-Schindler, U.; Collins, L.G. Hematite in porous red-clouded feldspars: Evidence of large-scale crustal fluid-rock interaction. Lithos 2007, 95, 10-18. [CrossRef]

33. Arth, J. Behaviour of trace elements during magmatic process summary of theoretical models and their applications. J. Res. U.S. Geol. Surv. 1976, 4, 41-47.

34. Kynaston, H.; Mellor, E.T.; Swinburne, U.P. The Geology of the Waterberg Tin-Fields; Geological Survey of Pretoria: Pretoria, South Africa, 1909; p. 124.

35. Norrish, K.; Hutton, J.T. An accurate X-ray spectrographic method for the analysis of geologic samples. Geochem. Cosmochim. Acta 1969, 33, 431-454. [CrossRef]

36. Wilson, A.H. A chill sequence to the Bushveld Complex: Insight into the first stage of emplacement and implications for the parental magmas. J. Petrol. 2012, 53, 1123-1168. [CrossRef]

37. Labuschagne, L.S. Evolution of the ore-forming fluids in the Rooiberg tin field, South Africa. Mem. Counc. Geosci. 2004, 126.

38. Frost, C.D.; Frost, B.R. On ferroan (a-type) granitoids: Their compositional variability and modes of origin. J. Petrol. 2011, 52, 39-53. [CrossRef] 
39. Gao, P.; Zheng, Y.F.; Zhao, Z.F. Experimental melts from crustal rocks: A lithochemical constraint on granite petrogenesis. Lithos 2016. [CrossRef]

40. Jiang, H.; Li, W.Q.; Jiang, S.Y.; Wang, H.; Wei, X.P. Geochronological, geochemical and Sr-Nd-Hf isotopic constraints on the petrogenesis of late cretaceous a-type granites from the Sibumasu Block, Southern Myanmar, SE Asia. Lithos 2016. [CrossRef]

41. Juniper, D.N.; Kleeman, J.D. Geochemical characterisation of some tin-mineralising granites of new South Wales. J. Geochem. Explor. 1979, 11,321-333. [CrossRef]

42. Li, H.; Watanabe, K.; Yonezu, K. Geochemistry of a-type granites in the Huangshaping polymetallic deposit (South Hunan, China): Implications for granite evolution and associated mineralization. J. Asian Earth Sci. 2014, 88, 149-167. [CrossRef]

43. Singh, L.G.; Vallinayagam, G. Petrological and geochemical constraints in the origin and associated mineralization of a-type granite suite of the Dhiran Area, Northwestern Peninsular India. Geosciences 2012. [CrossRef]

44. Zhou, G.; Wu, Y.; Wang, H.; Qin, Z.; Zhang, W.; Zheng, J.; Yang, S. Petrogenesis of the Huashanguan a-type granite complex and its implications for the early evolution of the Yangtze Block. Precambrian Res. 2017, 292, 57-74. [CrossRef]

45. Walraven, F. Stratigraphy and structure of the Nebo Granite, Bushveld Complex, South Africa. Abstr. Geocongress 1986, 86, 637-642.

46. Frost, B.R.; Barnes, C.G.; Collins, W.J.; Arculus, R.J.; Ellis, D.J.; Frost, C.D. A geochemical classification for granitic rocks. J. Petrol. 2001, 42, 2033-2048. [CrossRef]

47. Huang, W.-L.; Wyllie, P. Phase relationships of S-type granite with $\mathrm{H}_{2} \mathrm{O}$ to $35 \mathrm{kbar}$ : Muscovite granite from Harney Peak, South Dakota. J. Geophys. Res. Solid Earth 1981, 86, 10515-10529. [CrossRef]

48. Luth, W.C. The systems $\mathrm{NaAlSi}_{3} \mathrm{O}_{8}-\mathrm{SiO}_{2}$ and $\mathrm{KAlSi}_{2} \mathrm{O}_{8}$ to $20 \mathrm{~kb}$ and the relationship between $\mathrm{H}_{2} \mathrm{O}$ content, $\mathrm{P}_{\mathrm{H} 2 \mathrm{O}}$ in granitic magmas. Am. J. Sci. 1969, 267-A, 325-341.

49. Tuttle, O.F.; Bowen, N.L. Origin of Granite in the Light of Experimental Studies in the System: NaAlSi3O8; Geological Society of America: Boulder, CO, USA, 1958; p. 153.

50. Anderson, J.L. Proterozoic anorogenic granite plutonism of North America. Geol. Soc. Am. 1983, 161, 133-154.

51. Bartoli, O.; Acosta-Vigil, A.; Ferrero, S.; Cesare, B. Granitoid magmas preserved as melt inclusions in high-grade metamorphic rock. Am. Mineral. 2016, 101, 1543-1559. [CrossRef]

52. Wyllie, P.J. Crustal anatexis: An experimental review. Tectonophysics 1977, 43, 41-71. [CrossRef]

53. Bacon, C.R.; Druitt, T.H. Compositional evolution of the zoned calcalkaline magma chamber of Mount Mazama, Crater Lake, Oregon. Contrib. Mineral. Petrol. 1988, 98, 224-256. [CrossRef]

54. Bea, F.; Pereira, M.; Stroh, A. Mineral/leucosome trace-element partitioning in a peraluminous migmatite (a laser ablation-ICP-MS study). Chem. Geol. 1994, 117, 291-312. [CrossRef]

55. Sisson, T. Hornblende-melt trace-element partitioning measured by ion microprobe. Chem. Geol. 1994, 117, 331-344. [CrossRef]

56. Nash, W.; Crecraft, H. Partition coefficients for trace elements in silicic magmas. Geochim. Cosmochim. Acta 1985, 49, 2309-2322. [CrossRef]

57. Butler, J.; Bowden, P.; Smith, A. K/Rb ratios in the evolution of the Younger Granites of Northern Nigeria. Geochim. Cosmochim. Acta 1962, 26, 89-100. [CrossRef]

58. Shaw, D. A review of K-Rb fractionation trends by covariance analysis. Geochim. Cosmochim. Acta 1968, 32, 573-601. [CrossRef]

59. Aseri, A.A.; Linnen, R.L.; Che, X.D.; Thibault, Y.; Holtz, F. Effects of fluorine on the solubilities of Nb, Ta, $\mathrm{Zr}$ and Hf minerals in highly fluxed water-saturated haplogranitic melts. Ore Geol. Rev. 2015, 64, 736-746. [CrossRef]

60. Ballouard, C.; Poujol, M.; Boulvais, P.; Branquet, Y.; Tartese, R.; Vigneresse, J.-L. Nb-Ta fractionation in peraluminous granites: A marker of the magmatic-hydrothermal transition. Geology 2016, 44, 231-234. [CrossRef]

61. Dostal, J.; Chatterjee, A.K. Contrasting behaviour of $\mathrm{Nb} / \mathrm{Ta}$ and $\mathrm{Zr} / \mathrm{Hf}$ ratios in a peraluminous granitic pluton (Nova Scotia, Canada). Chem. Geol. 2000, 163, 207-218. [CrossRef]

62. Green, T.; Pearson, N. An experimental study of $\mathrm{Nb}$ and Ta partitioning between Ti-rich minerals and silicate liquids at high pressure and temperature. Geochim. Cosmochim. Acta 1987, 51, 55-62. [CrossRef] 
63. Green, T.H. Significance of $\mathrm{Nb} / \mathrm{Ta}$ as an indicator of geochemical processes in the crust-mantle system. Chem. Geol. 1995, 120, 347-359. [CrossRef]

64. Bonin, B. A-type granites and related rocks: Evolution of a concept, problems and prospects. Lithos 2007, 97, 1-29. [CrossRef]

65. Walraven, F.; Hattingh, E. Geochronology of the Nebo Granite, Bushveld Complex. S. Afr. J. Geol. 1993, 96, 31-41.

66. Collins, W.J.; Beams, S.D.; White, A.J.R.; Chappell, B.W. Nature and origin of a-type granites with particular reference to Southeastern Australia. Contrib. Mineral. Petrol. 1982, 80, 189-200. [CrossRef]

67. Whalen, J.B.; Currie, K.L.; Chappell, B.W. A-type granites: Geochemical characteristics, discrimination and petrogenesis. Contrib. Mineral. Petrol. 1987, 95, 407-419. [CrossRef]

68. McDonough, W.F.; Sun, S.S. The composition of the earth. Chem. Geol. 1995, 120, 223-253. [CrossRef]

69. Sun, S.-S.; McDonough, W.F. Chemical and isotopic systematics of oceanic basalts: Implications for mantle composition and processes. Geol. Soc. Lond. Spec. Publ. 1989, 42, 313-345. [CrossRef]

70. Fourie, D.S.; Harris, C. O-isotope study of the Bushveld Complex granites and granophyres: Constrains on source composition and assimilation. J. Petrol. 2011, 52, 2221-2242. [CrossRef]

71. Dill, H.G. The "chessboard" classification scheme of mineral deposits: Mineralogy and geology from aluminum to zirconium. Earth Sci. Rev. 2010, 100, 1-420. [CrossRef]

72. Štemprok, M. Greisenization (a review). Geol. Rundsch. 1987, 76, 169-175. [CrossRef]

73. Viswanathan, $\mathrm{S}$. Geochemical behaivour of $\mathrm{Rb}, \mathrm{Ba}, \mathrm{Pb}, \mathrm{Ti}, \mathrm{Mn}$ and $\mathrm{Zn}$ during progressive chloritization of granitic biotites. Curr. Sci. Assoc. 1972, 41, 655-658.

74. Bau, M. Controls on the fractionation of isovalent trace elements in magmatic and aqueous systems: Evidence from Y/Ho, Zr/Hf, and lanthanide tetrad effect. Contrib. Mineral. Petrol. 1996, 123, 323-333. [CrossRef]

75. Pan, Y. Controls on the fractionation of isovalent trace elements in magmatic and aqueous systems: Evidence from $\mathrm{Y} / \mathrm{Ho}, \mathrm{Zr} / \mathrm{Hf}$, and lanthanide tetrad effect-a discussion of the article by M. Bau (1996). Contrib. Mineral. Petrol. 1997, 128, 405-408. [CrossRef]

76. Zaraisky, G.P.; Aksyuk, A.M.; Devyatova, V.N.; Udoratina, O.V.; Chevychelov, V.Y. The Zr/Hf Ratio as a fractionation indicator of rare-metal granites. Petrology 2009, 17, 25-45. [CrossRef]

77. Simons, B.; Andersen, J.C.; Shail, R.K.; Jenner, F.E. Fractionation of Li, Be, Ga, Nb, Ta, In, Sn, Sb, W and Bi in the peraluminous early permian Variscan granites of the Cornubian Batholith: Precursor processes to magmatic-hydrothermal mineralisation. Lithos 2017, 278, 491-512. [CrossRef]

78. Halter, W.E.; Williams-Jones, A.E.; Kontak, D.J. Origin and evolution of the greisenizing fluid at the East Kemptville tin deposit, Nova Scotia, Canada. Econ. Geol. 1998, 93, 1026-1051. [CrossRef]

79. Migdisov, A.A.; Williams-Jones, A. Hydrothermal transport and deposition of the rare earth elements by fluorine-bearing aqueous liquids. Miner. Depos. 2014, 49, 987-997. [CrossRef]

80. Nagaseki, H.; Hayashi, K.-I. Experimental study of the behavior of copper and zinc in a boiling hydrothermal system. Geology 2008, 36, 27-30. [CrossRef]

81. Sherman, D. Metal complexation and ion association in hydrothermal fluids: Insights from quantum chemistry and molecular dynamics. Geofluids 2010, 10, 41-57.

82. Robb, L. Introduction to Ore-Forming Processes; Blackwell Publishing: Oxford, UK, 2005; p. 373.

83. Winter, J.D.N. Principles of Igneous and Metamorphic Petrology; Prentice Hall: Upper Saddle River, NJ, USA, 2010; p. 702.

84. Heinrich, C.A.; Gunther, D.; Audétat, A.; Ulrich, T.; Frischknecht, R. Metal fractionation between magmatic brine and vapor, determined by microanalysis of fluid inclusions. Geology 1999, 27, 755-758. [CrossRef]

85. Taylor, J.R.; Wall, V.J. Cassiterite solubility, tin speciation, and transport in a magmatic aqueous phase. Econ. Geol. 1993, 88, 437-460. [CrossRef]

86. Hong, W.; Cooke, D.R.; Zhang, L.; Fox, N.; Thompson, J. Tourmaline-rich features in the Heemskirk and Pieman Heads granites from western Tasmania, Australia: Characteristics, origins, and implications for tin mineralization. Am. Mineral. 2017, 102, 876-899. [CrossRef]

87. Duchoslav, M.; Marks, M.; Drost, K.; McCammon, C.; Marschall, H.; Wenzel, T.; Markl, G. Changes in tourmaline composition during magmatic and hydrothermal processes leading to tin-ore deposition: The Cornubian Batholith, SW England. Ore Geol. Rev. 2017, 83, 215-234. [CrossRef]

88. Wolf, M.B.; London, D. Boron in granitic magmas: Stability of tourmaline in equilibrium with biotite and cordierite. Contrib. Mineral. Petrol. 1997, 130, 12-30. [CrossRef] 
89. Heinrich, C.A. Fluid-fluid interactions in magmatic-hydrothermal ore formation. Rev. Mineral. Geochem. 2007, 65, 363-387. [CrossRef]

90. Heinrich, C.A. The chemistry of hydrothermal tin (-tungsten) ore deposition. Econ. Geol. 1990, 85, 457-481. [CrossRef]

91. Walker, F.D.L.; Lee, M.R.; Parsons, I. Micropores and micropermeable texture in alkali feldspars: Geochemical and geophysical implications. Mineral. Mag. 1995, 59, 505-534. [CrossRef]

92. Candela, P.A. Physics of aqueous phase evolution in plutonic environments. Am. Mineral. 1991, 76, 1081-1091.

93. London, D.; Morgan, G.B.; Hervig, R.L. Vapor-undersaturated experiments with Macusani glass $+\mathrm{H}_{2} \mathrm{O}$ at $200 \mathrm{MPa}$, and the internal differentiation of granitic pegmatites. Contrib. Mineral. Petrol. 1989, 102, 1-17. [CrossRef]

94. London, D. Stability of tourmaline in peraluminous granite systems: The boron cycle from anatexis to hydrothermal aureoles. Eur. J. Mineral. 1999, 11, 253-262. [CrossRef]

95. Drivenes, K.; Larsen, R.B.; Müller, A.; Sørensen, B.E.; Wiedenbeck, M.; Raanes, M.P. Late-magmatic immiscibility during batholith formation: Assessment of B isotopes and trace elements in tourmaline from the Land's End granite, SW England. Contrib. Mineral. Petrol. 2015, 169, 56. [CrossRef]

96. Williamson, B.; Spratt, J.; Adams, J.; Tindle, A.; Stanley, C. Geochemical constraints from zoned hydrothermal tourmalines on fluid evolution and Sn mineralization: An example from fault breccias at Roche, SW England. J. Petrol. 2000, 41, 1439-1453. [CrossRef]

(C) 2020 by the authors. Licensee MDPI, Basel, Switzerland. This article is an open access article distributed under the terms and conditions of the Creative Commons Attribution (CC BY) license (http://creativecommons.org/licenses/by/4.0/). 